\title{
Heteromeric Neuronal Nicotinic Acetylcholine Receptors with Mutant $\beta$ Subunits Acquire Sensitivity to $\alpha 7$-Selective Positive Allosteric Modulators
}

\author{
Clare Stokes, Sumanta Garai, Abhijit R. Kulkarni, Lucas N. Cantwell, Colleen M. Noviello, \\ Ryan E. Hibbs, Nicole A. Horenstein, Khalil A. Abboud, Ganesh A. Thakur, \\ and Roger L. Papke
}

\begin{abstract}
Departments of Pharmacology and Therapeutics (C.S., R.L.P.) and Chemistry (N.A.H., K.A.A.), University of Florida, Gainesville, Florida; Department of Pharmaceutical Sciences, School of Pharmacy, Bouvé College of Health Sciences, Northeastern University, Boston, Massachusetts (S.G., A.R.K., L.N.C., G.A.T.); and Department of Neuroscience, University of Texas
\end{abstract} Southwestern Medical Center, Dallas, Texas (C.M.N., R.E.H.)

Received April 25, 2019; accepted June 4, 2019

\begin{abstract}
Homomeric $\alpha 7$ nicotinic acetylcholine receptors (nAChR) have an intrinsically low probability of opening that can be overcome by $\alpha 7$-selective positive allosteric modulators (PAMs), which bind at a site involving the second transmembrane domain (TM2). Mutation of a methionine that is unique to $\alpha 7$ at the $15^{\prime}$ position of TM2 to leucine, the residue in most other nAChR subunits, largely eliminates the activity of such PAMs. We tested the effect of the reverse mutation $\left(L^{\prime} 15^{\prime} M\right)$ in heteromeric $n A C h R$ receptors containing $\alpha 4$ and $\beta 2$, which are the nAChR subunits that are most abundant in the brain. Receptors containing these mutations were found to be strongly potentiated by the $\alpha 7$ PAM 3a,4,5,9b-tetrahydro-4-(1-naphthalenyl)-3H-cyclopentan[c] quinoline-8-sulfonamide (TQS) but insensitive to the alternative PAM 1-(5-chloro-2,4-dimethoxyphenyl)-3-(5-methylisoxazol-3$\mathrm{yl})$-urea. The presence of the mutation in the $\beta 2$ subunit was necessary and sufficient for TQS sensitivity. The primary effect of the mutation in the $\alpha 4$ subunit was to reduce responses to acetylcholine applied alone. Sensitivity to TQS required only a single mutant $\beta$ subunit, regardless of the position of the mutant $\beta$ subunit within the pentameric complex. Similar results were obtained when $\beta 2 \mathrm{~L} 15^{\prime} \mathrm{M}$ was coexpressed with $\alpha 2$ or $\alpha 3$ and when the L15'M mutation was placed in $\beta 4$ and
\end{abstract}

coexpressed with $\alpha 2, \alpha 3$, or $\alpha 4$. Functional receptors were not observed when $\beta 1 \mathrm{~L} 15^{\prime} \mathrm{M}$ subunits were coexpressed with other muscle nAChR subunits. The unique structure-activity relationship of PAMs and the $\alpha 4 \beta 2 \mathrm{~L} 15^{\prime} \mathrm{M}$ receptor compared with $\alpha 7$ and the availability of high-resolution $\alpha 4 \beta 2$ structures may provide new insights into the fundamental mechanisms of $\mathrm{nAChR}$ allosteric potentiation.

\section{SIGNIFICANCE STATEMENT}

Heteromeric neuronal nAChRs have a relatively high initial probability of channel activation compared to receptors that are homomers of $\alpha 7$ subunits but are insensitive to PAMs, which greatly increase the open probability of $\alpha 7$ receptors. These features of heteromeric $\mathrm{nAChR}$ can be reversed by mutation of a single residue present in all neuronal heteromeric nAChR subunits to the sequence found in $\alpha 7$. Specifically, the mutation of the TM2 $15^{\prime}$ leucine to methionine in $\alpha$ subunits reduces heteromeric receptor channel activation, while the same mutation in neuronal $\beta$ subunits allows heteromeric receptors to respond to select $\alpha 7$ PAMs. The results indicate a key role for this residue in the functional differences in the two main classes of neuronal $n A C h R s$.

\section{Introduction}

The two main nicotinic acetylcholine receptors (nAChRs) in the brain can be identified by their high-affinity binding either

This research was supported by the National Institutes of Health [Grants R01-NS095899 and R01-DA042072 (to R.E.H.), Grant R01-GM57481 (to R.L.P.), and Grant RO1-EY024717 (to G.A.T.)].

https://doi.org/10.1124/jpet.119.259499.

S This article has supplemental material available at jpet.aspetjournals.org. to acetylcholine (ACh) and nicotine or to $\alpha$-bungarotoxin (Clarke et al., 1985). Receptors with high affinity for ACh and nicotine are heteromeric pentamers combining $\alpha$ and non- $\alpha(\beta)$ subunits, the most widely expressed subunits being $\alpha 4$ and $\beta 2$ (Wada et al., 1989). The receptors binding $\alpha$-bungarotoxin are strongly expressed in the hippocampus and other brain areas related to cognition and function as homomeric pentamers containing the $\alpha 7$ subunit (Wada et al., 1989). The expression pattern of $\alpha 7 \mathrm{nAChRs}$ suggested that

ABBREVIATIONS: A-867744, 4-(5-(4-chlorophenyl)-2-methyl-3-propionyl-1H-pyrrol-1-yl)benzenesulfonamide; ACh, acetylcholine; ago-PAM, allosteric activating positive allosteric modulator; 4BP, 4-(4-bromophenyl); CAP, cholinergic anti-inflammatory pathway; cryo-EM, electron microscopy; GAT107, (3aR,4S,9bS)-4-(4-bromophenyl)-3a,4,5,9b-tetrahydro-3H-cyclopenta[c]quinoline-8-sulfonamide; GAT927, 4-(4,5,6,7-tetrahydrobenzo[b]thiophen-3-yl)-3a,4,5,9b-tetrahydro-3H-cyclopenta[c]quinoline-8-sulfonamide; HS, high sensitivity; LS, low sensitivity; nAChR, nicotinic acetylcholine receptor; PAM, positive allosteric modulator; PNU-120596, 1-(5-chloro-2,4-dimethoxyphenyl)-3-(5-methylisoxazol-3-yl)-urea; $P_{\text {open }}$, probability of opening; TM2, second transmembrane domain; TQS, 3a,4,5,9b-tetrahydro-4-(1-naphthalenyl)-3H-cyclopentan[c]quinoline-8-sulfonamide. 
they might be a target for the treatment of Alzheimer's disease and other cognitive disorders (Levin and Rezvani, 2000; Mazurov et al., 2006). Also, $\alpha 7 \mathrm{nAChRs} \mathrm{play} \mathrm{an} \mathrm{essential} \mathrm{role}$ in non-neuronal cells as mediators of a cholinergic antiinflammatory pathway (CAP) (Wang et al., 2003; RosasBallina and Tracey, 2009).

As noted previpusly, $\alpha 7 \mathrm{nAChRs}$ have low affinity for ACh. However, in heterologous expression systems they most effectively activate in the same micromole ACh concentration range that best activates heteromeric receptors such as those containing $\alpha 4$ and $\beta 2$ subunits (Papke and Thinschmidt, 1998; Papke and Porter Papke, 2002). The key difference between these two main neuronal nAChR subtypes relates to their desensitization processes. After a brief period of high-probability channel opening, heteromeric receptors convert to desensitized states that bind $\mathrm{ACh}$ and nicotine with high affinity (Campling et al., 2013). Under normal conditions, $\alpha 7$ receptors never open with high probability and rapidly enter nonconducting desensitized states that are associated with high levels of agonist binding and are unique to $\alpha 7$ (Uteshev et al., 2002; Williams et al., 2012).

Our understanding of the unique activation and desensitization properties of $\alpha 7 \mathrm{nAChRs}$ has been advanced by the discovery of numerous positive allosteric modulators (PAMs) that selectively affect $\alpha 7$ receptors (Williams et al., 2011b). The most efficacious of these agents, identified as type II PAMs (Grønlien et al., 2007), appear to promote a unique conformational state associated with the destabilization of nonconducting desensitized states, resulting in protracted bursts of channel opening (Williams et al., 2011a; Andersen et al., 2016). The potential therapeutic utility of these PAMs for both central nervous system (Williams et al., 2011b) and peripheral indications such as inflammatory pain (Freitas et al., 2013; Bagdas et al., 2016) is an active area of research.

Investigations of the structural basis for $\alpha 7$ PAM activity have been impeded by the lack of high-resolution crystal structures or homology models of $\alpha 7$ that include the poreforming transmembrane domains. Nonetheless, studies of receptor chimeras and mutants, using the 5HT3A receptor sequence as a negative control, have generated good evidence for a PAM binding site associated with the first and second transmembrane domains (TM2) (Young et al., 2008). The sequence of the pore-forming TM2 (Akabas et al., 1994) is highly conserved among the nAChR subunits (Fig. 1).

Starting with $\alpha 7 / 5 \mathrm{HT} 3 \mathrm{~A}$ chimeras, two point mutations were identified that had equivalently large effects on reducing 1-(5-chloro-2,4-dimethoxyphenyl)-3-(5-methylisoxazol3-yl)-urea (PNU-120596) potentiation (Young et al., 2008). One mutant, $\alpha 7 \mathrm{~A} 226 \mathrm{D}$, substituted a residue that is unique to 5HT3A (Fig. 1) for a residue that is present in $\alpha 7$, but also in several other $\mathrm{nAChR}$ subunits. The single most important residue for the $\alpha 7$-selective PAM activity of PNU-129596, which is unique to the $\alpha 7$ sequence, was the methionine residue at the $15^{\prime}$ position (residue 254 in the human $\alpha 7$ ). Since the conversion of this residue to a leucine, which is the corresponding residue in most other nAChR subunits (all but $\alpha 7$ and $\alpha 10$ ), causes the essential loss of $\alpha 7$ PAM activity (Young et al., 2008; Quadri et al., 2019), we tested the effects of the reverse mutation $\left(\mathrm{L} 15^{\prime} \mathrm{M}\right)$ on the sensitivity of heteromeric nAChR to PAMs that are normally only effective on $\alpha 7$ receptors.

We report that this single point mutation in neuronal $\beta$ subunits is sufficient to generate heteromeric nAChRs that are sensitive to potentiation by select $\alpha 7$ PAMs. Furthermore, this site in $\alpha 4 \beta 2 \mathrm{nAChR}$ differentiates among structural classes of PAMs differently than it does in $\alpha 7$ receptors. The structure-activity profile of PAMs active on $\alpha 4 \beta 2$ mutants and the availability of crystallographic and cryo-electron microscopy (cryo-EM) structures of $\alpha 4 \beta 2$ (Morales-Perez et al., 2016; Walsh et al., 2018) may provide new insights into the nature of this allosteric modulation.

\section{Materials and Methods}

\section{Commercial Reagents}

Acetylcholine chloride, atropine, and other chemicals were purchased from Sigma-Aldrich Chemical Company (St. Louis, MO), and (3aR,4S,9bS)-4-(4-bromophenyl)-3a,4,5,9b-tetrahydro-3H-cyclopenta [c]quinoline-8-sulfonamide (GAT107) (Kulkarni and Thakur, 2013; Thakur et al., 2013), 3-(3,4-difluorophenyl)- $N$-(1-(6-(4-(pyridin-2-yl) piperazin-1-yl)pyrazin-2-yl)ethyl)propenamide (Garai et al., 2018), and PNU-120596 (Williams et al., 2011a) were synthesized as described previously. Fresh ACh stock solutions were made in Ringer's solution each day of experimentation. Stock solutions of the PAMs were made in DMSO and kept at $-20^{\circ} \mathrm{C}$ and then diluted in Ringer's solution each day . $\begin{array}{ll}\text { alpha9 } & \text { SFYIVNLLIPCVLISFLAPLSFYLPAASG-EKVSLGVTILLAMTVFQLMVAEI } \\ \text { alpha10 } & \text { AAYVCNLLLPCVLISLLAPLAFHLPADSG-EKVSLGVTVLLALTVFQLLLAES } \\ \text { gamma } & \text { LFYVINIIAPCVLISSVAILIHFLPAKAGGQKCTVAINVLLAQTVFLFLVAKK } \\ \text { epsilon } & \text { LFYVINIIVPCVLISGLVLLAYFLPAQAGGQKCTVSINVLLAQTVFLFLIAQK } \\ \text { delta } & \text { LFYIINILVPCVLISFMVNLVFYLPADSG-EKTSVAISVLLAQSVFLLLISKR } \\ \text { beta1 } & \text { LFYLVNVIAPCILITLLAIFVFYPPDAG-EKMGLSIFALLTLTVFLLLLADK } \\ \text { alpha1 } & \text { LYFIVNVIIPCLLFSFTGLVFYPTDSG-EKMTLSISVLLSLTVFLLVIVEL } \\ \text { alpha5 } & \text { LFYTLFLIIPCIGLSFLTVLVFYLSNEG-EKICLCTSVLVSLTVFLLVIEEI } \\ \text { beta3 } & \text { LFYTLFLIIPCLGLSFLTLVFYPSDEG-EKLSLSTSVLVSLTVLLVIEEI } \\ \text { alpha6 } & \text { MFYTINLIIPCLFISFLTVLVFYLPSCG-EKVTLCISVLLSLTVFLLVITET } \\ \text { alpha2 } & \text { LFYTINLIIPCLLISCLTVLVFYPSDCG-EKITLCISVLLSLTVFLLLITEI } \\ \text { alpha3 } & \text { LFYTINLIIPCLLISFLTVLVFYLPSDCG-EKVTLCISVLLSLTVFLLVITET } \\ \text { alpha4 } & \text { LFYTINLIIPCLLISCLTVLVFYLPSECG-EKITLCISVLLSLTVFLLLITEI } \\ \text { beta4 } & \text { LFYTINLIIPCVLTTLLAILVFYLPDCG-EKMTLCISVLLALTFFLLLISKI } \\ \text { beta2 } & \text { LFYTINLIIPCVLITSLAILVFYLPSCG-EKMTLCISVLLALTVFLLLISKI } \\ \text { alpha7 } & \text { LYYGLNLLIPCVLISALALLVFLLPADSG-EKISLGITVLLSLTVFMLLVAEI } \\ & \text { TM1 }\end{array}$

5 HT 3 a
LFYVVSLLLPS IFLMVMDIVGFYLPPNSG-ERVSFKITLLLGYSVFLI IVSDT 226
Fig. 1. Amino acid sequences of $n A C h R$ subunits in the first transmembrane domain (TM1) and TM2 compared with the sequence of the 5 HT3A receptor. The two residues shown to be most important in controlling the potentiating activity of PNU-120596 on $\alpha 7$ receptors (Young et al., 2008) are highlighted. Note that the aspartic acid (D) residue at 226 ( $\alpha 7$ numbering) in TM1 is unique to 5HT3A. The sequences in TM2 are aligned such that a local numbering system (Miller, 1989) for this subdomain can be applied. The 1 ' position, closest to the intracellular domain, is to the left and the $20^{\prime}$ position is to the right. The other residue that was most critical for PNU-120596 potentiation was the $15^{\prime}$ methionine (M254), which is unique to $\alpha 7$. 


\section{Compound Synthesis}

4-(4,5,6,7-Tetrahydrobenzo[b]Thiophen-3-yl)-3a,4,5,9bTetrahydro-3H-Cyclopenta[c]Quinoline-8-Sulfonamide. 4,5,6,7Tetrahydrobenzo $[b]$ thiophene-3-carbaldehyde $(100 \mathrm{mg}, 0.6 \mathrm{mM})$, sulfanilamide (103 mg, $0.6 \mathrm{mM})$, and indium chloride ( $40 \mathrm{mg}, 0.18 \mathrm{mM}$ ) were dissolved in anhydrous acetonitrile in a $10 \mathrm{ml}$ microwave vial. Freshly distilled cyclopentadiene ( $119 \mathrm{mg}, 1.8 \mathrm{mM}$ ) was added to the reaction mixture and irradiated under microwave for 15 minutes at $60^{\circ} \mathrm{C}$. The reaction mixture was quenched with saturated aqueous solution $\mathrm{Na}_{2} \mathrm{CO}_{3}$. The aqueous layer was extracted with ethyl acetate $(3 \times 5 \mathrm{ml})$ and the combined organic layer was dried over anhydrous $\mathrm{Na}_{2} \mathrm{SO}_{4}$ followed by evaporation under reduced pressure. The crude reaction mixture was purified by silica gel column chromatography to yield pure 4-(4,5,6,7-tetrahydrobenzo[b]thiophen3 -yl)-3a,4,5,9b-tetrahydro-3H-cyclopenta $[c]$ quinoline-8-sulfonamide (GAT927) (224 mg, 98\%) as an off-white solid. The following parameters were used: ${ }^{1} \mathrm{H}$ NMR $(\mathrm{CDCl} 3,500 \mathrm{MHz}): \delta 7.59(\mathrm{~s}, 1 \mathrm{H})$, $7.51(\mathrm{dd}, \mathrm{J}=8.6,2.0 \mathrm{~Hz}, 1 \mathrm{H}), 7.03(\mathrm{~s}, 1 \mathrm{H}), 6.63(\mathrm{~d}, \mathrm{~J}=8.4 \mathrm{~Hz}, 1 \mathrm{H})$, 5.85-5.84 (m, 1H), 5.70-5.69 (m, 1H), 4.64-4.62 (m, 3H), $4.16(\mathrm{~s}, 1 \mathrm{H})$, $4.07(\mathrm{~d}, \mathrm{~J}=9.7 \mathrm{~Hz}, 1 \mathrm{H}), 3.08-3.02(\mathrm{~m}, 1 \mathrm{H}), 2.82-2.79(\mathrm{~m}, 2 \mathrm{H}), 2.61-2.51$ $(\mathrm{m}, 3 \mathrm{H}), 1.97-1.92(\mathrm{~m}, 1 \mathrm{H})$, and $1.90-1.78(\mathrm{~m}, 4 \mathrm{H})$; and mass spectrometry electrospray ionization (mass-to-charge ratio): $387[\mathrm{M}+\mathrm{H}]+$

4-(5-(4-Chlorophenyl)-2-Methyl-3-Propionyl-1H-Pyrrol-1-yl) Benzenesulfonamide. 4-(5-(4-Chlorophenyl)-2-methyl-3-propionyl$1 H$-pyrrol-1-yl)benzenesulfonamide (A-867744) was synthesized using our modified synthetic route in one step from ethyl 5-(4-chlorophenyl)-2methyl-1-(4-sulfamoylphenyl)- $1 H$-pyrrole-3-carboxylate instead of the reported four steps from the same intermediate 1 (Faghih et al., 2009). Ethyl 5-(4-chlorophenyl)-2-methyl-1-(4-sulfamoylphenyl)- $1 H$-pyrrole-3carboxylate was synthesized by following the reported protocol from 2bromo-1-(4-chlorophenyl)ethenone (Faghih et al., 2009) and used for the synthesis of A-867744 according to the following procedure.

Ethyl 5-(4-chlorophenyl)-2-methyl-1-(4-sulfamoylphenyl)-1H-pyrrole-3-carboxylate $(200 \mathrm{mg}, 0.478 \mathrm{mmol})$ and N,O-dimethyl hydroxylamine $(56 \mathrm{mg}, 0.574 \mathrm{mmol})$ were dissolved with anhydrous tetrahydrofuran in a 100-ml flame-dried two-neck round-bottom flask under argon atmosphere. The reaction mixture was cooled to $0^{\circ} \mathrm{C}$ and ethylmagneisum bromide solution in tetrahydrofuran was added dropwise to the reaction mixture. The reaction mixture was stirred at $0^{\circ} \mathrm{C}$ for 30 minutes and then quenched with saturated solution $\mathrm{NH}_{4} \mathrm{Cl}$. The aqueous layer was extracted with ethyl acetate, dried over $\mathrm{Na}_{2} \mathrm{SO}_{4}$, and concentrated under reduced pressure. The reaction mixture was purified by silica gel column chromatography to obtain the pure desired compound A-867744 $(39 \mathrm{mg}, 21 \%) .{ }^{1} \mathrm{H}$ NMR (CDCl3, $500 \mathrm{MHz}$ ): $\delta 7.98(\mathrm{~d}, \mathrm{~J}=8.8 \mathrm{~Hz}, 2 \mathrm{H}), 7.28(\mathrm{~d}, \mathrm{~J}=8.2$ $\mathrm{Hz}, 2 \mathrm{H}), 7.17(\mathrm{~d}, \mathrm{~J}=7.7 \mathrm{~Hz}, 2 \mathrm{H}), 8.95(\mathrm{~d}, \mathrm{~J}=8.2 \mathrm{~Hz}, 2 \mathrm{H}), 6.74$ (s, 1H), $4.89(\mathrm{bs}, 2 \mathrm{H}), 2.87(\mathrm{q}, \mathrm{J}=7.1 \mathrm{~Hz}, 2 \mathrm{H}), 2.44(\mathrm{~s}, 3 \mathrm{H})$, and 1.22 $(\mathrm{t}, \mathrm{J}=7.1 \mathrm{~Hz}, 3 \mathrm{H}$ ); and mass spectrometry electrospray ionization (mass-to-charge ratio): $403[\mathrm{M}+\mathrm{H}]+$.

Chiral Separation of 3a,4,5,9b-Tetrahydro-4-(1-Naphthalenyl)$3 \boldsymbol{H}$-Cyclopentan[c]Quinoline-8-Sulfonamide. Racemic $3 a, 4,5,9 b$ tetrahydro-4-(1-naphthalenyl)-3H-cyclopentan $[c]$ quinoline-8-sulfonamide (TQS) was synthesized as previously described (Gill et al., 2012). Since it was not known whether both isomers of TQS were active, we separated the isomers by preparative high-performance liquid chromatography. Specifically, preparative supercritical fluid chromatography was performed using a Chiralcel OD-H with super fluid and methanol (50/50) as a mobile phase at a $5.0 \mathrm{ml} / \mathrm{min}$ flow rate. Thus, from a $1.0 \mathrm{~g}$ batch of racemic TQS, we obtained $455 \mathrm{mg}$ of (-)-enantiomer 1a (specific optical rotation: $-56.89 ; \mathrm{MeOH} ; \mathrm{c}=0.450 / 100 \mathrm{ml}$ ) and $455 \mathrm{mg}$ of (+)-enantiomer $1 \mathrm{~b}$ (specific optical rotation: $+61.75 ; \mathrm{MeOH} ; \mathrm{c}=0.434 / 100 \mathrm{ml}$ ).

\section{X-Ray Analysis of TQS Crystals}

X-Ray intensity data were collected at $100 \mathrm{~K}$ on a Bruker DUO diffractometer using $\mathrm{MoK} \alpha$ radiation $(\lambda=0.71073 \AA)$ and an APEXII CCD area detector. Raw data frames were read by the SAINT1 software program and integrated using three-dimensional profiling algorithms. The resulting data were reduced to produce hkl reflections, their intensities, and estimated S.D. The data were corrected for Lorentz and polarization effects, and numerical absorption corrections were applied based on indexed and measured faces.

The structure was solved and refined in SHELXTL2014 (BrukerAXS, Madison, WI) using full-matrix least-squares refinement. The non-H atoms were refined with anisotropic thermal parameters, and all of the $\mathrm{H}$ atoms were calculated in idealized positions and refined riding on their parent atoms. The correct stereochemistry of the molecule is the one refined as confirmed by the low Flack $x$ parameter of 0.007(9), determined by anomalous dispersion. All three protons on C2, C3, and C4 are syn to each other (lying on the same side of the average molecular plane). In the final cycle of refinement, 6884 reflections [of which 6242 are observed with $I>2 \sigma(I)$ ] were used to refine 256 parameters, and the resulting $\mathrm{R} 1$, wR2, and $\mathrm{S}$ (goodness of fit) values were $3.85 \%, 10.22 \%$, and 1.062 , respectively. The refinement was carried out by minimizing the wR2 function using $F_{2}$ rather than $F$ values; R1 was calculated to provide a reference for the conventional $R$ value, but its function was not minimized.

\section{Molecular Modeling}

The coordinates for the structure of $\alpha 4 \beta 2$ are from the Research Collaboratory for Structural Bioinformatics entry 6CNJ (Walsh et al., 2018). The energy minimization of small molecules in Fig. 13 was done in ChemBio3D Ultra (PerkinElmer). Schrodinger Glide (Cambridge, MA) was used for docking.

Heterologous Expression of nAChRs in Xenopus laevis Oocytes. The human $\alpha 9$ clone, codon optimized for Xenopus laevis, was obtained from Veronika Grau and Katrin Richter (Giessen University, Giessen, Germany). Other human nAChR clones and concatamers were obtained from Dr. J. Lindstrom (University of Pennsylvania, Philadelphia, PA). The human resistance-to-cholinesterase 3 clone, obtained from Dr. M. Treinin (Hebrew University, Jerusalem, Israel), was coinjected with $\alpha 7$ to improve the level and speed of $\alpha 7$ receptor expression without affecting the pharmacological properties of the receptors (Halevi et al., 2003). Subsequent to linearization and purification of the plasmid cDNAs, complementary RNAs were prepared using the mMessage mMachine in vitro RNA transfection kit (Ambion, Austin, TX). Site-directed mutants were made using the QuikChange kit (Agilent, Santa Clara CA) as previously described (Papke et al., 2011).

Oocytes were surgically removed from mature Xenopus laevis frogs (Nasco, Ft. Atkinson, WI) and injected with appropriate nAChR subunit complementary RNAs as described previously (Papke and Stokes, 2010). Frogs were maintained in the Animal Care Service Facility at the University of Florida, and all procedures were approved by the University of Florida Institutional Animal Care and Use Committee. In brief, the frog was first anesthetized for 15-20 minutes in $1.5 \mathrm{l}$ frog tank water containing $1 \mathrm{~g}$ of 3 aminobenzoate methanesulfonate buffered with sodium bicarbonate. The harvested oocytes were treated with $1.25 \mathrm{mg} / \mathrm{ml}$ collagenase (Worthington Biochemicals, Freehold, NJ) for 2 hours at room temperature in calcium-free Barth's solution $(88 \mathrm{mM} \mathrm{NaCl}, 1 \mathrm{mM}$ $\mathrm{KCl}, 2.38 \mathrm{mM} \mathrm{NaHCO}$, $0.82 \mathrm{mM} \mathrm{MgSO} 4,15 \mathrm{mM}$ HEPES, and $12 \mathrm{mg} / \mathrm{l}$ tetracycline, $\mathrm{pH}$ 7.6) to remove the follicular layer. Stage V oocytes were subsequently isolated and injected with $50 \mathrm{nl}$ of 5-20 ng nAChR subunit complementary RNA. Recordings were carried out 1-7 days after injection.

Two-Electrode Voltage Clamp Electrophysiology. Experiments were conducted at room temperature $\left(24^{\circ} \mathrm{C}\right)$ using OpusXpress 6000A (Molecular Devices, Union City, CA) (Papke and Stokes, 2010). Both the voltage and current electrodes were filled with $3 \mathrm{M} \mathrm{KCl}$. Oocytes were voltage-clamped at $-60 \mathrm{mV}$. The oocytes were bath perfused with Ringer's solution (115 mM NaCl, $2.5 \mathrm{mM} \mathrm{KCl}, 1.8 \mathrm{mM}$ $\mathrm{CaCl} 2,10 \mathrm{mM}$ HEPES, and $1 \mu \mathrm{M}$ atropine, $\mathrm{pH} 7.2)$ at $2 \mathrm{ml} / \mathrm{min}(\alpha 7$ and $\alpha 9$ ) or at $4 \mathrm{ml} / \mathrm{min}$ (heteromeric). Drug applications were 12 seconds in duration followed by a 181-second washout period ( $\alpha 7$ and $\alpha 9$ ) or 
6 seconds in duration followed by a 241-second washout period (heteromeric). A typical recording for each oocyte constituted two initial control applications of ACh, an experimental compound applied alone or coapplied with $\mathrm{ACh}$, and then follow-up control applications of ACh to determine primed potentiation of the AChevoked responses. The control ACh concentration was $30 \mu \mathrm{M}$ unless otherwise indicated. The responses were calculated as both peak current amplitudes and net charge, as previously described (Papke and Porter Papke, 2002). The average responses of the two initial ACh controls from each cell were used for normalization. Statistical analyses were conducted based on $t$ test comparisons of the normalized net-charge data.

Data were collected at $50 \mathrm{~Hz}$, filtered at $20 \mathrm{~Hz}(\alpha 7$ and $\alpha 9)$ or $5 \mathrm{~Hz}$ (heteromeric), and analyzed by Clampfit 9.2 or 10.3 (Molecular Devices) and Excel (Microsoft, Redmond, WA). Data were expressed as mean \pm S.E.M. values from at least four oocytes for each experiment and plotted by Kaleidagraph 4.5.2 (Abelbeck Software, Reading, PA). Type II PAMs produce extremely large increases (>100,000-fold) in the single-channel currents of a small fraction of the receptors $(\leq 1 \%)$, which means they are intrinsically variable in amplitude and duration (Williams et al., 2011a), making it difficult to identify truly representative responses. Therefore, we display multicell averages for comparisons of these complex responses. The averages of normalized data were calculated using an Excel (Microsoft) template for each of the 10,500 points in each of the 210 -second traces (acquired at $50 \mathrm{~Hz}$ ). Following subtraction of the basal holding current, data from each cell, including the ACh controls, were normalized by dividing each point by the peak of the ACh control from the same cell. The normalized data were then averaged and the S.E.M. for the multicell averages was calculated on a point-by-point basis. In the figures, the dark lines represent the average normalized currents, the shaded areas represent the range of the S.E.M., and the scale bars of averaged traces reflect the scaling factor relative to the average peak current amplitude of the ACh controls used for the normalization procedures. These plots are effectively augmented versions of typical bar plots of peak currents (Supplemental Fig. 1) that additionally illustrate the differences in net charge, the kinetics of the responses, and the variability throughout the entire time course of the responses.

\section{Results}

Effects of L15'M Mutations in Receptors Formed by the Coexpression of $\alpha 4$ and $\beta 2$. Cells expressing $\alpha 4 \mathrm{~L} 15^{\prime} \mathrm{M}$ and $\beta 2 \mathrm{~L} 15^{\prime} \mathrm{M}$ were tested for their responses to applications of ACh applied alone or coapplied with the previously identified type II $\alpha 7$ PAMs, PNU-120596 (Hurst et al., 2005) or TQS (Grønlien et al., 2007). While the coapplication of PNU-120596 had no effect on the ACh-evoked responses, $10 \mu \mathrm{M}$ TQS produced a very large increase in the ACh-evoked responses $(P<0.00001$ for peak current amplitudes $)$, which did not readily return to baseline (Fig. 2, see also Supplemental Fig. 1).

Impact of L15'M Mutations in $\alpha 4$ and $\beta 2$, Alone or in Combination. We evaluated the impact of the L15'M mutations in either or both subunits of $\alpha 4 \beta 2$ receptors compared with responses of receptors formed with wild-type subunits. All groups of cells were injected on the same day and tested 7 days after injection. The control ACh peak current responses of cells with either the $\alpha 4 \mathrm{~L} 15^{\prime} \mathrm{M}$ mutation $\left(\alpha 4^{*} \beta 2\right)$ or $\beta 2 \mathrm{~L} 15^{\prime} \mathrm{M}$ mutation $\left(\alpha 4^{*} \beta 2\right)$ were less than wildtype $\alpha 4 \beta 2 \mathrm{ACh}$ responses $(P<0.05)$ but were still reasonably robust. However, the ACh control responses of the double mutants $\left(\alpha 4^{*} \beta 2^{*}\right)$ were severely compromised compared with wild type $(P<0.001)$, reduced to only about $5 \%$ of wild-type control responses (Fig. 3A).

Responses to ACh plus $10 \mu \mathrm{M}$ TQS compared with ACh alone in the same cells were greatly increased in cells containing $\beta 2 \mathrm{~L} 15^{\prime} \mathrm{M}$ subunits $(P<0.001)$, regardless of

$$
\alpha 4{\mathrm{~L} 15^{\prime} \mathrm{M}}^{\prime} \beta 2{\mathrm{~L} 155^{\prime} \mathrm{M}}^{\prime}
$$

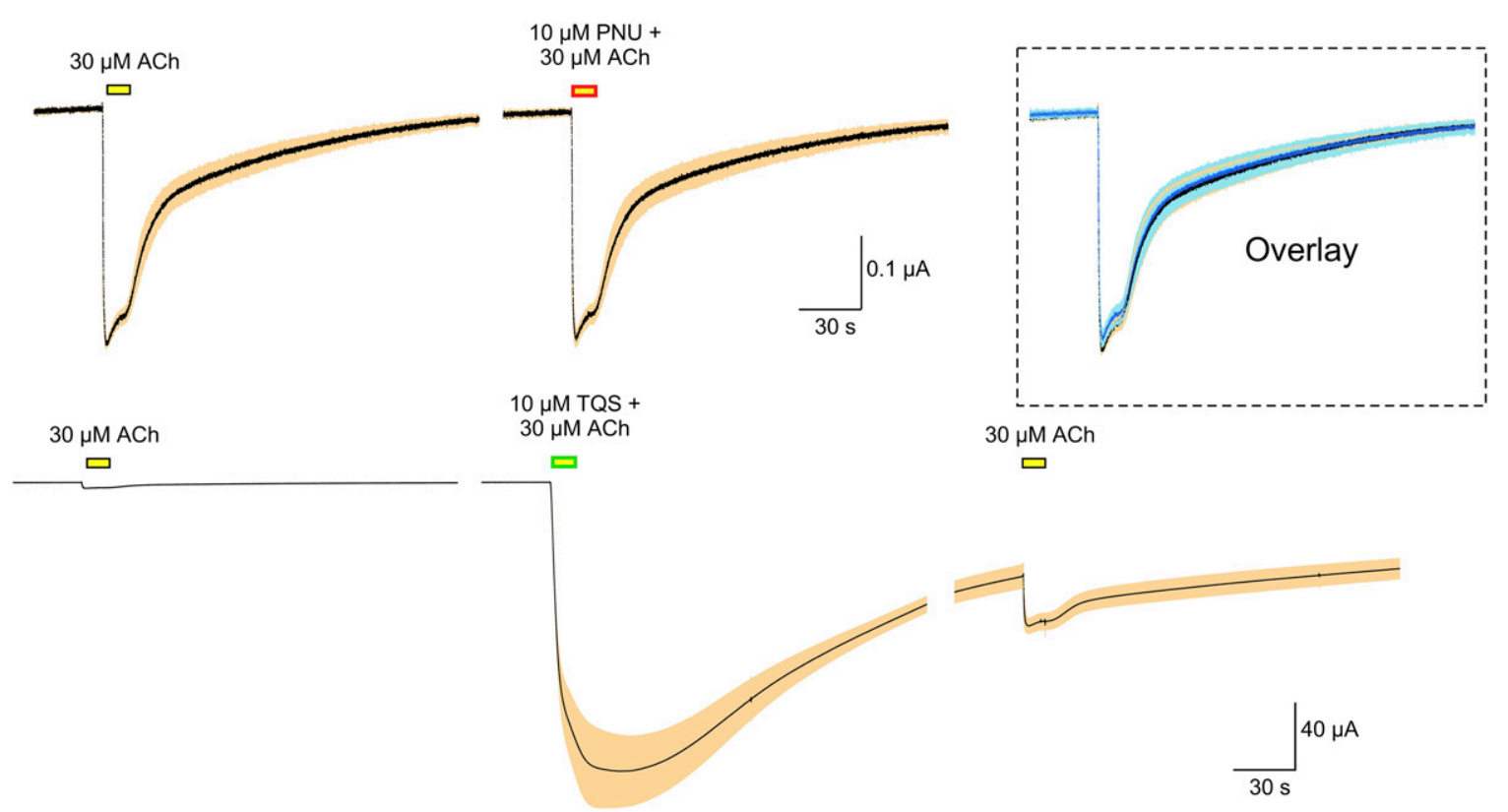

Fig. 2. $\alpha 4 \beta 2$ Double mutant data. Averaged raw data traces ( \pm S.E.M.) for $\alpha 4 \beta 2$ receptors with L15'M mutations in both subunits. Prior to averaging, the data from each cell were normalized to the peak amplitude of two initial $30 \mu \mathrm{M}$ ACh control responses (see Materials and Methods). The average amplitude of the ACh controls was $325 \pm 27 \mathrm{nA}$. The PNU-120596 data are the average of eight cells and the TQS data are the average of four cells. The inset in the upper panels is an overlay of the ACh controls and the responses to ACh plus $10 \mu \mathrm{M}$ PNU-120596. 
A

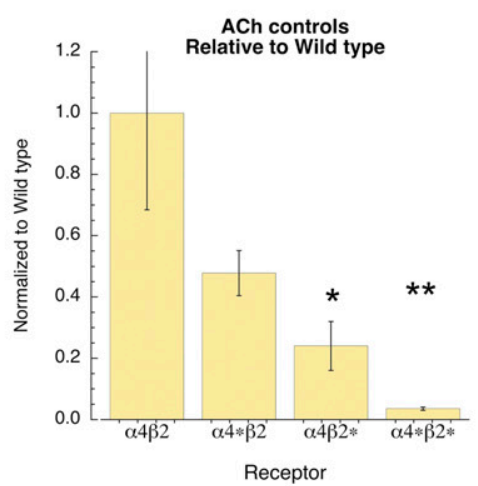

D

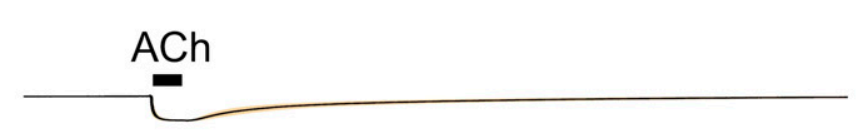

B

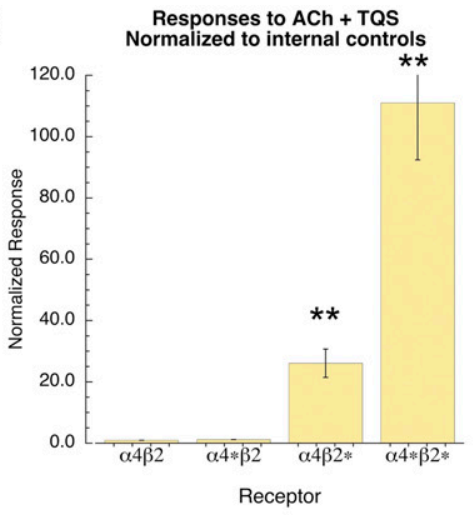

C Tos responses
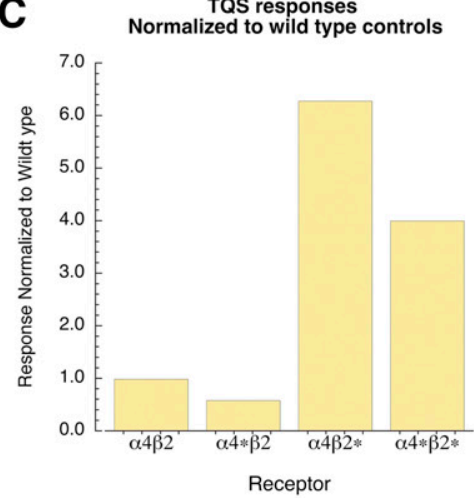

$\alpha 4_{\llcorner 15 \mathrm{M} M} \beta 2$

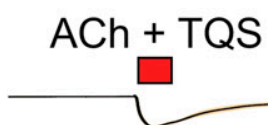

\section{$\alpha 4 \beta 2\llcorner$ 15'M}
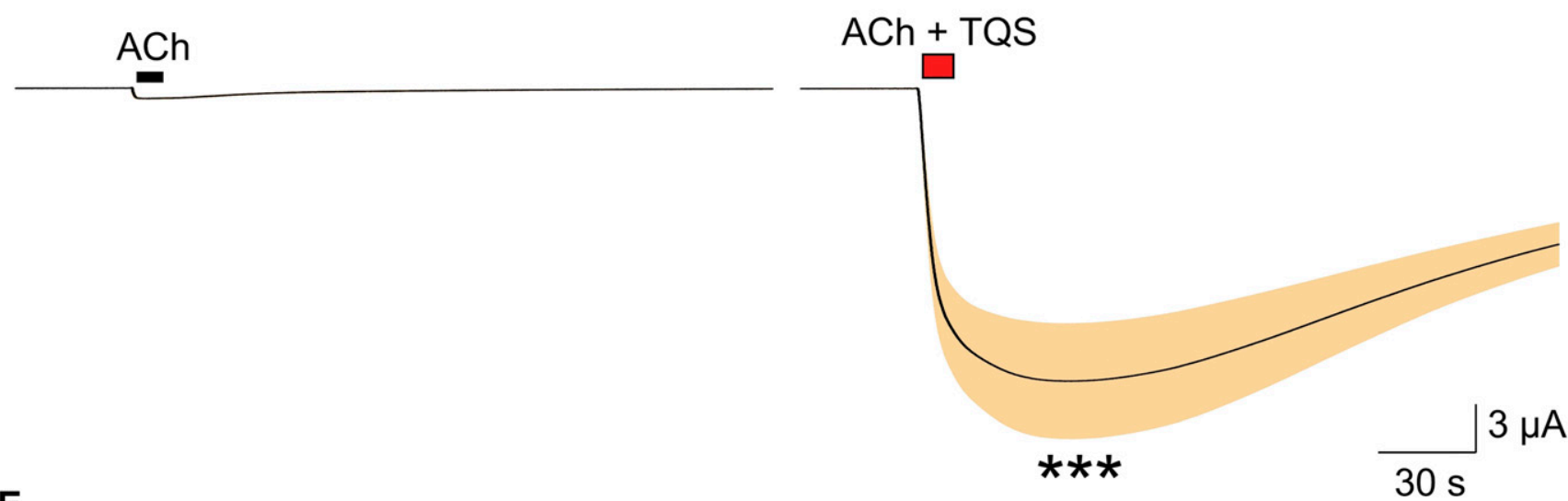

E

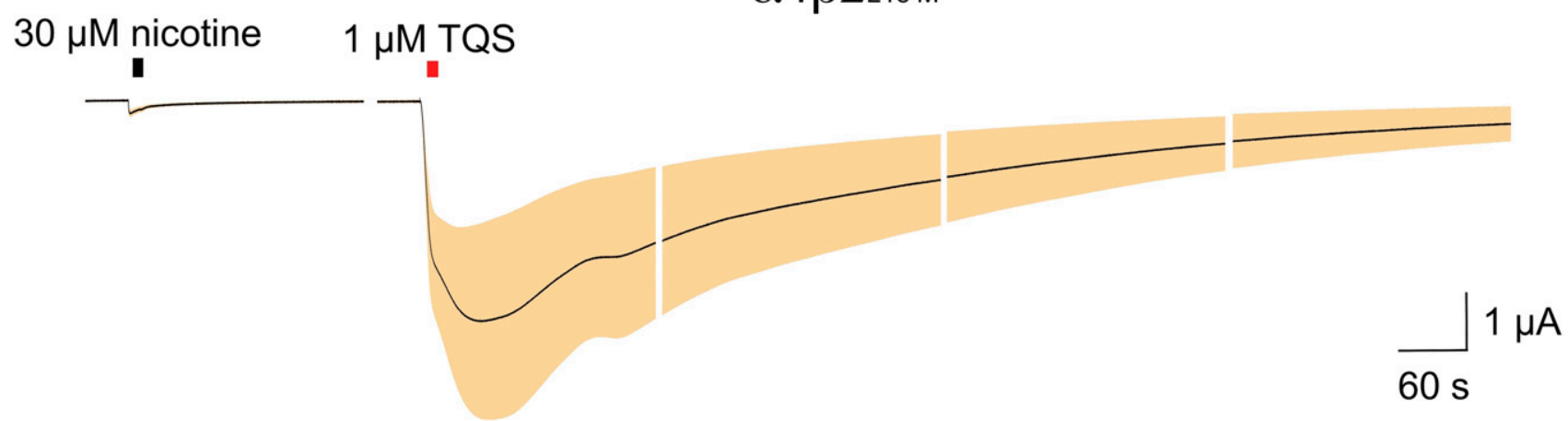

Fig. 3. $\alpha 4 \beta 2$ Receptors with L15'M mutations in both subunits or single subunits. (A) The average peak currents from cells recorded on the same day from different injection sets as indicated: $\alpha 4 \beta 2$ and wild-type subunits; $\alpha 4^{*} \beta 2, \alpha 4 \mathrm{~L} 15^{\prime} \mathrm{M}$, and wild-type $\beta 2$ subunits; $\alpha 4 \beta 2^{*}$, wild-type $\alpha 4$, and $\beta 2 \mathrm{~L} 15^{\prime} \mathrm{M}$ subunits; and $\alpha 4^{*} \beta 2^{*}, \alpha 4 \mathrm{~L} 15^{\prime} \mathrm{M}$, and $\beta 2 \mathrm{~L} 15^{\prime} \mathrm{M}$ subunits. The data are the average peak currents for $5-8$ oocytes. (B) Data from the same cells in (A), showing the responses to $30 \mu \mathrm{M}$ ACh plus $10 \mu \mathrm{M}$ TQS, normalized to the response to $30 \mu \mathrm{M}$ ACh alone in the same cells. (C) Data from (B) divided by the average ACh control of the wild-type cells in (A). (D) Averaged raw data for the ACh and ACh plus TQS responses of cells expressing the L15' M mutation in either the $\alpha 4$ subunit (upper trace, $n=7$ ) or $\beta 2$ subunit (lower trace, $n=4$ ). (E) Effects of TQS on desensitized receptors. After obtaining ACh control responses $30 \mu \mathrm{M}$ nicotine was applied to cells expressing $\alpha 4 \beta 2 \mathrm{~L} 15^{\prime} \mathrm{M}$ receptors. This concentration of nicotine results in reduction (desensitization) of approximately 55\% of the control ACh response (data not shown). Under these conditions, the application of $1 \mu \mathrm{M}$ TQS alone produced a large and protracted response $(n=8)$. The average responses, normalized to the initial ACh controls, are represented by the black line, and the shaded area shows the S.E.M. at each point. Each segment represents 210 seconds of recording. The amplitude scale bar is based on the average peak currents of the initial ACh control responses. 
whether the mutant $\beta$ subunit was coexpressed with wild-type $\alpha 4$ or $\alpha 4 \mathrm{~L} 15^{\prime} \mathrm{M}$. The relative potentiation of the double mutant $\alpha 4^{*} \beta 2^{*}$ was larger $(P<0.05)$ than that of the $\alpha 4 \beta 2^{*}$ receptors (Fig. 3B). However, comparison of the TQS-potentiated responses of the mutant receptors that were normalized to the average responses of the wild-type receptors recorded on the same day (Fig. 3C) indicated that the apparent large potentiation of the double mutants was due to the negative effect on ACh-evoked responses by the mutations in the $\alpha$ subunits (Fig. 3A); this limitation was partly reversed by TQS when mutant $\beta$ subunits were also present. The raw data shown in Fig. 3D clearly shows that the presence of the $\mathrm{L}^{\prime} 5^{\prime} \mathrm{M}$ mutation in $\beta 2$ was necessary for TQS to potentiate AChevoked responses, while the mutation in $\alpha 4$ alone had no effect on TQS sensitivity.

In addition to potentiating responses evoked by ACh or other orthosteric agonists, type II PAMs will also reactivate receptors previously desensitized (Papke et al., 2009; Williams et al., 2011a). We used an application of $30 \mu \mathrm{M}$ nicotine to desensitize $\alpha 4 \beta 2 \mathrm{~L} 15 \mathrm{M}$ receptors. In a separate experiment we determined that this concentration of nicotine reduced subsequent control $\mathrm{ACh}$ responses by $55 \%$ compared with initial controls $(P<0.01, n=8)$ and that ACh responses showed no significant recovery over the course of three ACh applications (data not shown). Under these conditions, where a large fraction of the $\alpha 4 \beta 2 \mathrm{~L} 15^{\prime} \mathrm{M}$ receptors was unresponsive to ACh, we applied $1 \mu \mathrm{M}$ TQS alone and determined that the addition of TQS was sufficient to draw receptors out of desensitization and back into activated states (Fig. 3E).

ACh and TQS Concentration-Response Studies of $\boldsymbol{\alpha} 4 \boldsymbol{\beta} 2 \mathrm{L15}$ 'M Receptors. The coexpression of $\alpha 4$ and $\beta 2$ subunits can potentially result in receptors with different subunit stoichiometry, $\alpha 4(3) \beta 2(2)$ or $\alpha 4(2) \beta 2(3)$ (Nelson et al., 2003), and unless influenced by the ratio of RNAs injected or constrained by the use of subunit concatamers (Zhou et al., 2003) mixed populations of receptors may be observed. When receptors are constrained to adopt the socalled high-sensitivity (HS) $\alpha 4(2) \beta 2(3)$ configuration, ACh response curves achieve maximum values at about $10 \mu \mathrm{M}$, and higher concentrations of $\mathrm{ACh}$ do not evoke larger responses. The alternative low-sensitivity (LS) $\alpha 4(3) \beta 2(2)$ configuration tends to generate larger currents more rapidly after injection, and due to the presence of a low-affinity ACh site at the $\alpha 4-\alpha 4$ interface (Harpsøe et al., 2011; Lucero et al., 2016) these receptors show increasing responses to ACh across a larger range of concentrations. Based on a twosite curve fit (Supplemental Fig. 2; Supplemental Table 1), the receptors resulting from the coinjection of $\alpha 4$ with $\beta 2 \mathrm{~L} 15^{\prime} \mathrm{M}$ appeared to form mostly HS-type receptors $(\approx 88 \%)$ with an $\mathrm{EC}_{50}$ value of $3 \mu \mathrm{M}$, but with a significant LS component $(\approx 10 \%)$ with an $\mathrm{EC}_{50}$ value of $281 \mu \mathrm{M}$ (Fig. 4A). This suggests that most of the receptors resulting from the coinjection of $\alpha 4$ wild-type and mutant $\beta 2$ had three mutant subunits per receptor.

The potentiation of $30 \mu \mathrm{M}$ ACh responses by TQS (Fig. 4B) showed an $\mathrm{EC}_{50}$ value of $1.8 \pm 0.3 \mu \mathrm{M}$ and an $E_{\max }$ value for the potentiation of peak currents of 13.6-fold \pm 0.8 -fold, relative to $\mathrm{ACh}$ alone. However, it should be noted that this efficacy estimate, based on the measurement of peak current, is clearly an underestimate of the overall effect of TQS on receptor activation. As shown in Fig. 4C, coapplication of ACh and TQS, especially at concentrations $\geq 3 \mu \mathrm{M}$, resulted in protracted responses that did not return to baseline even after several minutes of washout.

Evaluation of the TQS Analog, the Allosteric Activating Positive Allosteric Modulator GAT107. TQS has proven to be a valuable scaffold for the development of analogs with diverse properties (Gill-Thind et al., 2015; Horenstein et al., 2016), including 4-(4-bromophenyl) (4BP)-TQS (Gill et al., 2011) and its active isomer, GAT107 (Papke et al., 2014). While typical PAMs require coapplication with an orthosteric agonist, allosteric activating positive allosteric modulators (ago-PAMs) appear to work at two sites, the transmembrane site controlled by the $\alpha 7 \mathrm{M} 15^{\prime}$ residue and an allosteric activation site in the extracellular domain (Horenstein et al., 2016; Gulsevin et al., 2019). We evaluated the activity of the ago-PAM GAT107 on cells expressing $\alpha 4$ and $\beta 2 \mathrm{~L} 15$ 'M (Fig. 5). We observed a relatively small but significant $(P<0.01)$ increase in $\mathrm{ACh}$ responses when $10 \mu \mathrm{M}$ GAT107 was coapplied with ACh (Fig. 5A). We observed no allosteric activation when GAT107 was applied alone; however, there was a small residual (primed) potentiation $(P<0.05)$ of an $\mathrm{ACh}$ response after the application of GAT107 alone (Fig. 5B).

The Selectivity of Stereoisomers for the Potentiation $\alpha 4 \beta 2$ L15'M Receptors. Although the selectivity of stereoisomers has not been well investigated for most $\alpha 7 \mathrm{PAMs}$, as noted previously, 4BP-TQS can be separated into active (GAT107) and inactive (GAT106) isomers (Thakur et al., 2013). We confirmed that the 4BP-TQS isomer that lacked activity on $\alpha 7$ was likewise inactive on $\alpha 4 \beta 2 \mathrm{~L} 15^{\prime} \mathrm{M}$ receptors (Fig. 5C).

We prepared the corresponding isomers of TQS and determined that the active isomer was (-)-TQS (Fig. 5D). (-)-TQS was very active on both $\alpha 4 \beta 2 \mathrm{~L} 15^{\prime} \mathrm{M}$ and $\alpha 7$, producing robust potentiation at submicromolar concentrations that was greater than typically observed with the racemic preparation (Fig. 4), suggesting that the presence of the $(+)$ isomer might actually limit the responses to racemic TQS. To test this, we coapplied ACh with $300 \mathrm{nM}(-)-\mathrm{TQS}$ alone or with $3 \mu \mathrm{M}(+)-T Q S$ and confirmed that the inactive isomer functions as an antagonist of (-)-TQS (Fig. 5D).

The X-ray crystal structure of (-)-TQS is shown in Fig. 5E. The key stereo chemical features of GAT107, which is the active enantiomer of 4BP-TQS, are the same in the active TQS isomer (Fig. 5F). The structural differences that must account for the differences in the relative efficacy of these molecules for $\alpha 7$ and PAM-sensitive heteromeric receptors are highlighted in the overlay.

Evaluations of Additional PAMs. We determined that A-867744 (Faghih et al., 2009), an $\alpha 7$ PAM previously suggested to have a different mechanism of action compared with others (Newcombe et al., 2018), also had significant potentiating effects on $\alpha 4 \beta 2 \mathrm{~L} 15^{\prime} \mathrm{M}$ receptors; peak current responses to $30 \mu \mathrm{M}$ ACh were increased by a factor of 5.1 -fold \pm 0.6 -fold with coapplication of A-867744. The ago-PAM 3-(3,4-difluorophenyl)- $N$-(1-(6-(4-(pyridin-2-yl)piperazin-1-yl) pyrazin-2-yl)ethyl)propenamide (Post-Munson et al., 2017) had neither agonist nor PAM activity on $\alpha 4 \beta 2 \mathrm{~L} 15^{\prime} \mathrm{M}$ receptors (data not shown). Noting the structural difference between GAT107 and TQS (Fig. 5), we tested an alternative PAM, GAT927 (Fig. 6), which like TQS has a double ring structure at the base. Similar to effects of ago-PAMs on $\alpha 7$, GAT927 was able to activate $\alpha 4 \beta 2 \mathrm{~L} 15^{\prime} \mathrm{M}$ receptors when applied alone 


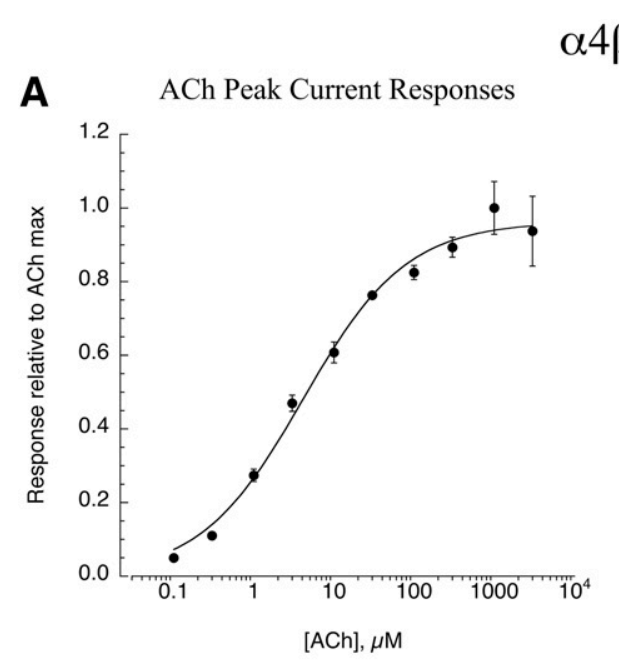

C
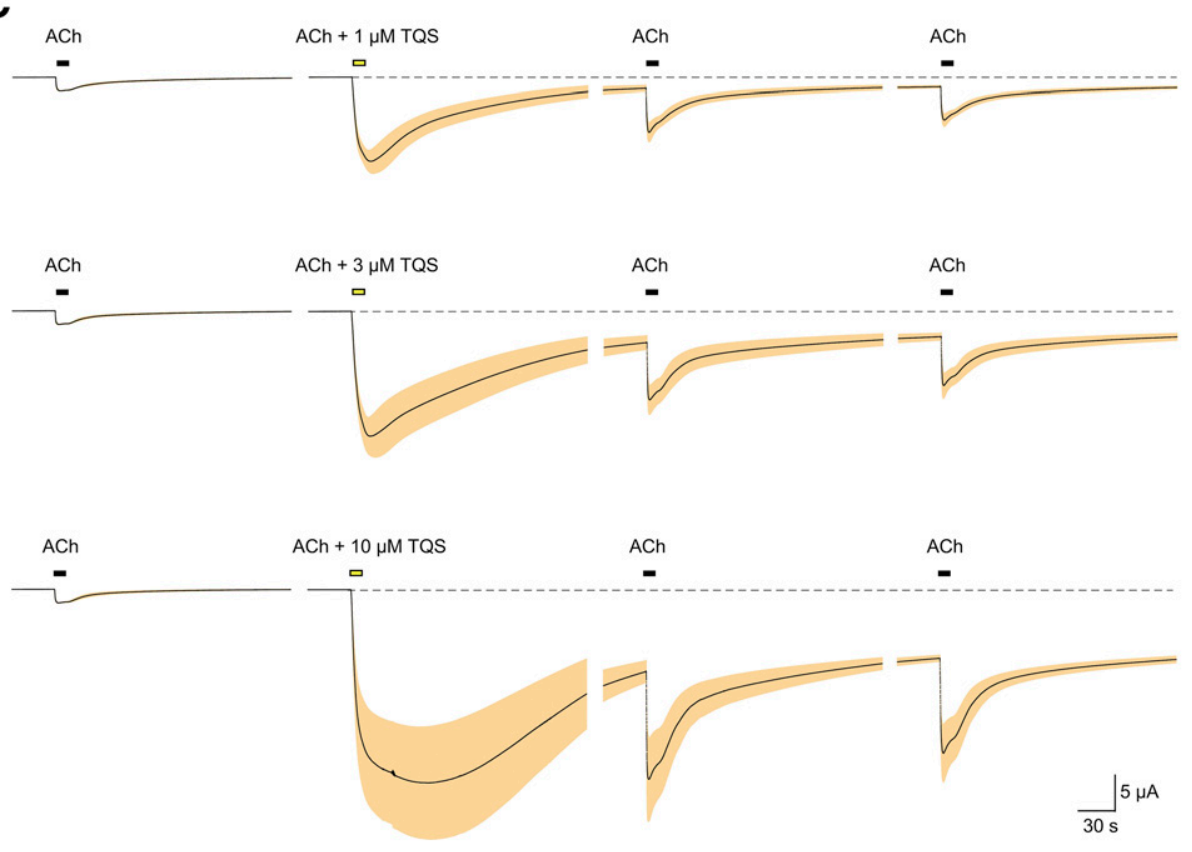

TQS Potentiation

B

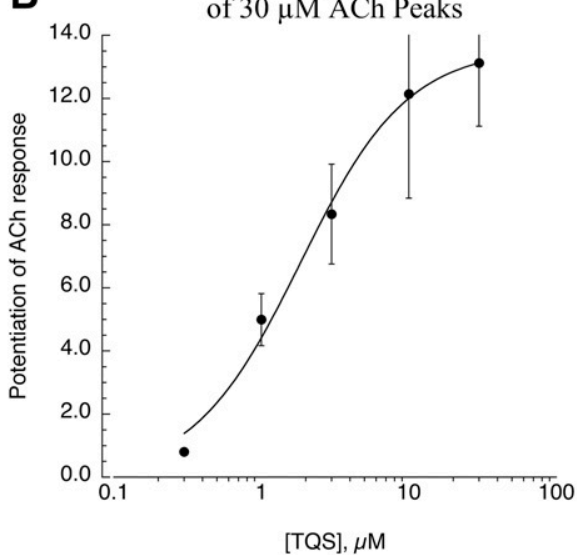

Fig. 4. ACh and TQS responses of $\alpha 4 \beta 2 \mathrm{~L} 15^{\prime} \mathrm{M}$ receptors. (A) The ACh concentration-response relationship of cells expressing wild-type $\alpha 4$ and $\beta 2 \mathrm{~L} 15^{\prime} \mathrm{M}$ subunits $(n=7)$. ACh was applied at progressively higher concentrations in alternation with repeated control applications of $30 \mu \mathrm{M}$ ACh to ensure that there was no rundown or cumulative desensitization through the course of the experiment. Data were normalized to the ACh maximum response. As noted in the text, the data could be fit by either a one- or two-site model. The curve fit shown is for the one-site model that indicated a value of $\mathrm{EC}_{50}=5.0 \pm 0.6 \mu \mathrm{M}$. (B) The concentrationresponse relationship for TQS potentiation of ACh responses of cells expressing wild-type $\alpha 4$ and $\beta 2 \mathrm{~L} 15^{\prime} \mathrm{M}$ subunits; the data are the average peak current responses from four to seven cells at the varying concentrations, normalized to their respective ACh controls. Cells could only be exposed to single TQS applications, and at the highest concentration several cells failed voltage clamp. (C) Averaged raw data traces for TQS-potentiated responses up to $10 \mu \mathrm{M}$ shown in (B), illustrating the protracted activation following single coapplications of ACh and TQS. Note that when ACh was applied again after the coapplication of $30 \mu \mathrm{M}$ ACh and $30 \mu \mathrm{M}$ TQS, all cells failed voltage clamp (data not shown).
(Fig. 6A), and this relatively modest allosteric activation was followed by a prolonged period of primed potentiation of subsequent ACh-evoked responses (Papke et al., 2014). The potency and efficacy of GAT927 for $\alpha 4 \beta 2 \mathrm{~L} 15^{\prime} \mathrm{M}$ receptors was so great that it could only be characterized across a limited range of concentrations. Although the allosteric activation produced by concentrations of GAT927 up to $300 \mu \mathrm{M}$ could be measured (Fig. 6B), responses to ACh following the application of GAT927 alone at concentrations $\geq 30 \mu \mathrm{M}$ were too large to voltage clamp. Likewise, responses to ACh coapplied with GAT927 concentrations $\geq 30 \mu \mathrm{M}$ were too large to voltage clamp (Fig. 6C).

Potentiating Effects of GAT927 on $\alpha 4 \beta 2$ Receptors with Varying Numbers of $\beta 2 L 15$ 'M Subunits. Using linked $\alpha 4 \beta 2$ subunits (Zhou et al., 2003) with or without the $\beta 2 \mathrm{~L} 15^{\prime} \mathrm{M}$ mutation and coexpressing them with wild-type $\beta 2$ or $\beta 2 \mathrm{~L} 15^{\prime} \mathrm{M}$, we were able to constrain the receptor composition to contain zero, one, two, or three mutant subunits (Fig. 7A). Comparing the responses of cells that were all injected at the same time, we determined that ACh control responses for receptors with multiple $\beta 2$ mutant subunits were significantly reduced compared with wild-type controls ( $n \geq 5, P<0.001$ ), similar to the effect of the L15'M mutation in the $\alpha 4$ subunits (Fig. 7B). The presence of the mutation in the single $\beta$ subunit in the accessory subunit position (outside the ACh binding sites) (Nelson et al., 2003) produced no significant effect on the amplitude of ACh control responses. While the relative effect of $3 \mu \mathrm{M}$ GAT927 coapplication with ACh to receptors with two or three mutant subunits was greater than the relative effects on receptors with a single mutant subunit (Fig. 7C), this appeared to be largely a relief of the effects of multiple mutants on basic ACh-evoked responses. The absolute magnitudes of the potentiated responses were not significantly different regardless of the number of mutant $\beta$ subunits (Fig. 7D). Additionally, the receptors with single mutant $\beta$ subunits showed more pronounced prolonged potentiation of subsequent ACh-evoked responses (Fig. 7, E and F). 
A

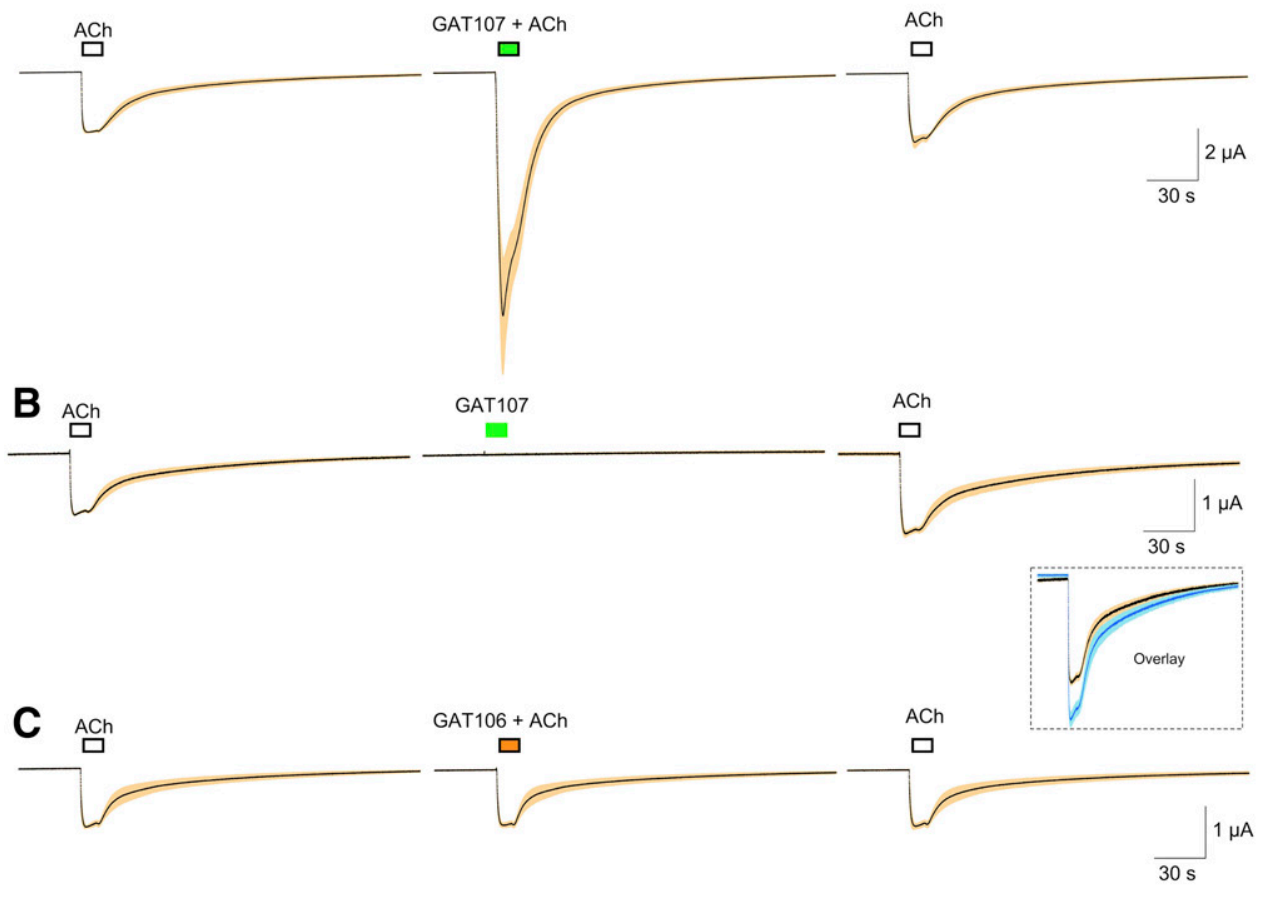

D $\alpha 4 \beta 2$ L15'M

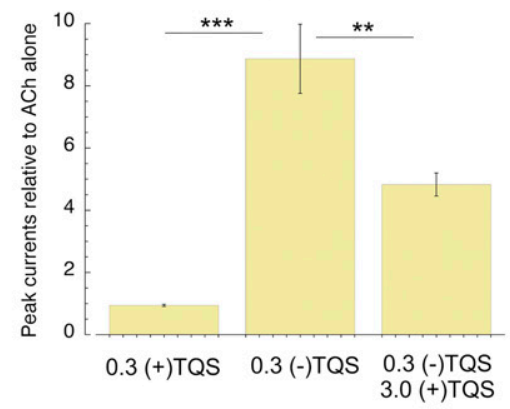

co-applied with ACh

$\mathbf{E}$

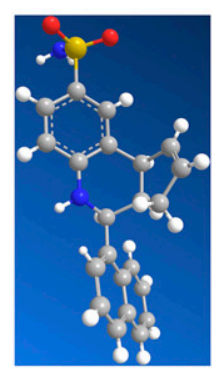

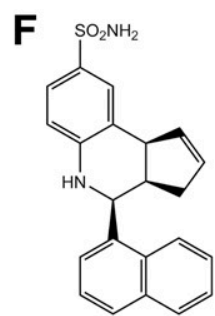

(-) TQS

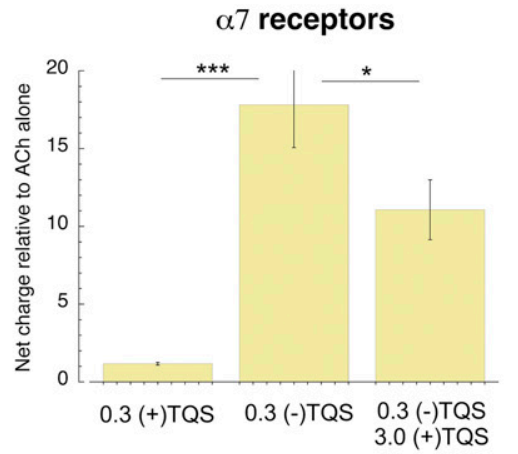

co-applied with ACh

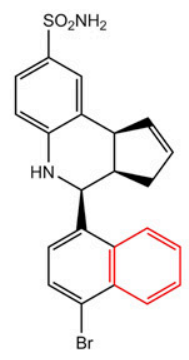

superposition

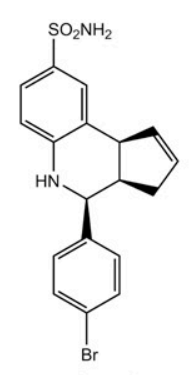

GAT 107
Fig. 5. Responses of $\alpha 4 \beta 2 \mathrm{~L} 15^{\prime} \mathrm{M}$ receptors to the ago-PAM GAT107 and its inactive isomer. (A) The coapplication $10 \mu \mathrm{M}$ GAT107 with $30 \mu \mathrm{M}$ ACh produced significant potentiation $(P<0.01$ $n=8$ ). (B) The application of $10 \mu \mathrm{M}$ GAT107 alone did not produce allosteric activation of $\alpha 4 \beta 2^{*}$ receptors. However, when ACh was applied following the application of GAT107 alone, there was significant residual potentiation $(P<$ $0.01 n=7$ ), as shown in the inset. (C) GAT106, the 4BP-TQS isomer that is inactive on $\alpha 7$ (Thakur et al., 2013), did not produce any potentiation of $\alpha 4 \beta 2 \mathrm{~L} 15$ 'M receptor ACh-evoked responses. (D) Activity of TQS isomers. Cells were injected with $\alpha 4$ and $\beta 2 \mathrm{~L} 15^{\prime} \mathrm{M}$ or wildtype $\alpha 7$. After two control applications of ACh $\left(30 \mu \mathrm{M}\right.$ for $\alpha 4 \beta 2 \mathrm{~L} 15^{\prime} \mathrm{M}$ or $60 \mu \mathrm{M}$ for $\alpha 7$ ), ACh was coapplied with $300 \mathrm{nM}$ of either the (+) or (-) isomer of TQS. Responses were normalized to the average of the ACh controls for each cell. (+)TQS produced no significant potentiation compared with ACh alone, while (-)-TQS significantly $(P<0.001)$ potentiated responses of both receptor types. The addition of $3 \mu \mathrm{M}(+)-\mathrm{TQS}$ decreased responses compared with responses obtained with $300 \mathrm{nM}$ (-)-TQS alone $\left(P<0.01, n=7\right.$ for $\alpha 4 \beta 2 L_{15}^{\prime} \mathrm{M} ; P<$ $0.05, n=8$ for $\alpha 7)$. $\alpha 4 \beta 2 \mathrm{~L} 15^{\prime} \mathrm{M}$ responses were measured as peak currents; $\alpha 7$ responses were measured as net charge. (E) The X-ray crystal structure determined for (-)-TQS (see Materials and Methods). (F) The structure is for (-)-TQS displaying the absolute stereochemistry, followed by an overlay structure for TQS and GAT107 (the red color highlights the fused benzene ring found in TQS, but not in GAT107), and on the far right the structure is for GAT107 showing absolute stereochemistry.
To confirm that a single mutant $\beta$ subunit would be sufficient to make receptors sensitive to $\alpha 7$ PAMs regardless of its position within the receptor, the alternative concatamer $\alpha 4-6-\beta 2$ (Zhou et al., 2003) was coexpressed with the L15'M $\beta 2$ mutant. This combination is also expected to produce receptors with a single mutant $\beta$; however, in this case the mutant would be in one of the two ACh binding site $\beta$ subunits, and the the wild type would be in the accessory $\beta$ subunit. The control responses of these cells to $30 \mu \mathrm{M}$ ACh were $280 \pm 3 \mathrm{nA}(n=7)$, and the coapplication of $10 \mu \mathrm{M}$ TQS with $30 \mu \mathrm{M}$ evoked responses that were 10.1-fold \pm 3 .4-fold larger than $\mathrm{ACh}$ alone $(P<$ 0.001 ; data not shown). While the presence of a $\beta 2 \mathrm{~L} 15^{\prime} \mathrm{M}$ subunit in the accessory subunit position did not significantly impact the amplitude of ACh controls, receptors formed by the coexpression of $\beta 2 \mathrm{~L} 15^{\prime} \mathrm{M}$ with the alternative concatamer $\alpha 4-6$ - $\beta 2$ had compromised ACh control responses $(P<0.05, n=8)$. Average peak responses were $162 \pm 19 \mathrm{nA}$ when the concatamer was coexpressed with wild-type $\beta 2$, and $97 \pm 15 \mathrm{nA}$ when coexpressed with $\beta 2 \mathrm{~L} 15^{\prime} \mathrm{M}$. 
A $\alpha 4 \beta 2\llcorner 15$ 'M

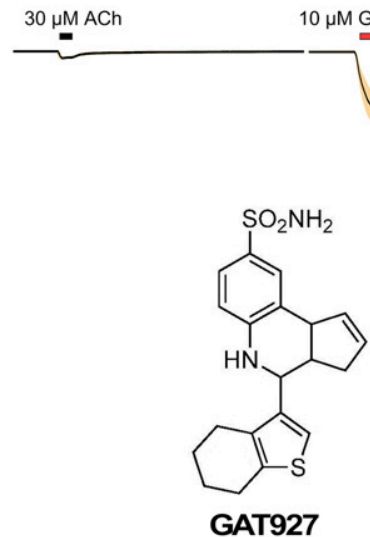

B

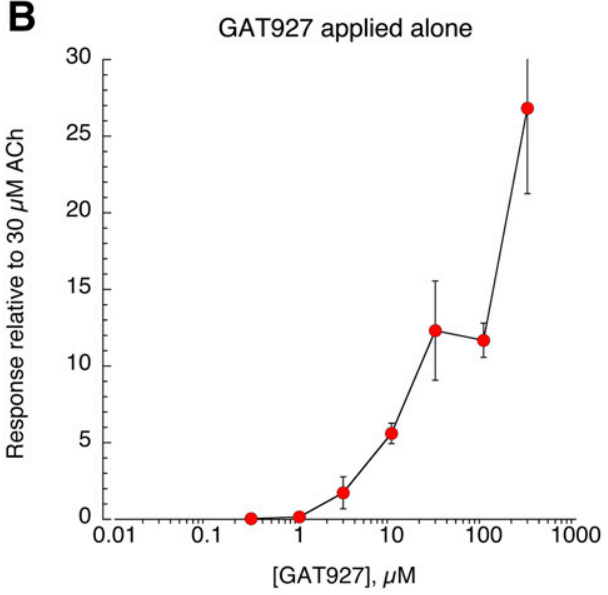

C

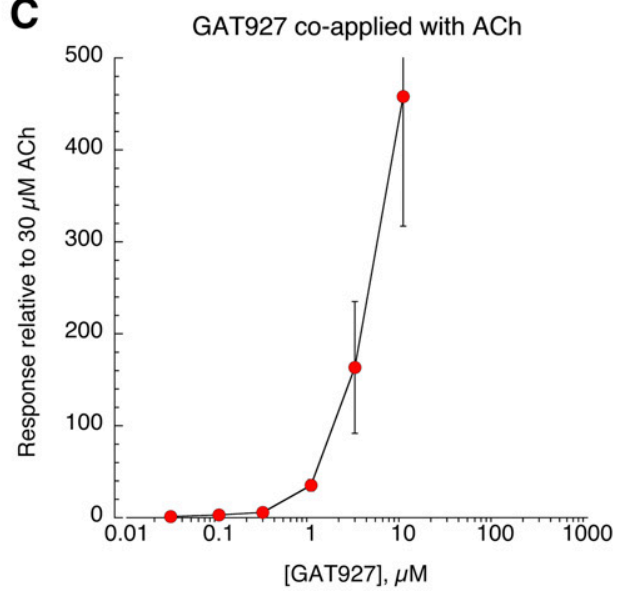

Fig. 6. Activation and potentiation of $\alpha 4 \beta 2 \mathrm{~L} 15^{\prime} \mathrm{M}$ receptors by the novel TQS analog GAT927. (A) The averaged normalized raw data $(n=5)$ for cells expressing $\alpha 4 \beta 2 \mathrm{~L} 15^{\prime} \mathrm{M}$ receptors to the application of $10 \mu \mathrm{M}$ GAT927 (structure shown in the inset). Note the strong potentiation of subsequent ACh applications following the application of GAT927. (B) Responses of $\alpha 4 \beta 2 \mathrm{~L} 15^{\prime} \mathrm{M}$ receptors to GAT927 applied alone. The data are averaged peak currents ( \pm S.E.M, $n=4-7)$, normalized to $30 \mu \mathrm{M}$ ACh control responses from the same cells. Note that following the application of concentrations of GAT927 $\geq 30 \mu \mathrm{M}$ applied alone, subsequent applications of ACh produced responses too large to be voltage clamped. These data were unsuitable to be fit to the Hill equation since there was no detectable plateau in the response. (C) Responses of $\alpha 4 \beta 2 \mathrm{~L} 15^{\prime} \mathrm{M}$ receptors to GAT927 coapplied with $30 \mu \mathrm{M}$ ACh. The data are averaged peak currents ( \pm S.E.M., $n=$ 4-7), normalized to $30 \mu \mathrm{M}$ ACh control responses from the same cells. Note that following the coapplication of concentrations of GAT927 $>10 \mu \mathrm{M}$, responses were too large to be voltage clamped. These data were unsuitable to be fit to the Hill equation since there was no detectable plateau in the response.
We also tested the impact of multiple L15'M mutations in receptors constrained to have the $\operatorname{LS} \alpha 4(3) \beta 2(2)$ configuration and obtained results consistent with the HS receptor results shown in Fig. 7 (Supplemental Fig. 3). Note that to form these receptors, we used the concatamer that places a $\beta 2 \mathrm{~L} 15^{\prime} \mathrm{M}$ in each of the ACh binding sites, and that the receptors with one or three mutations incorporated $\alpha 4 \mathrm{~L} 15^{\prime} \mathrm{M}$ subunits. All of these receptors had reduced $\mathrm{ACh}$ control responses, and those with two $\beta 2 \mathrm{~L} 15^{\prime} \mathrm{M}$ subunits were potentiated by $10 \mu \mathrm{M}$ TQS. The receptors with two $\beta 2 \mathrm{~L} 15^{\prime} \mathrm{M}$ subunits that lacked $\alpha 4 \mathrm{~L} 15^{\prime} \mathrm{M}$ were potentiated by the relatively low concentration of TQS used $(10 \mu \mathrm{M})$ only to a level equivalent to the wild-type control.

Since the location of a single mutant $\beta 2$ subunit in the accessory subunit position (Fig. 7) was sufficient to produce potentiation without a decrease in ACh control responses, we tested the ACh concentration responses of $\alpha 4(2) \beta 2(2) \beta 2 \mathrm{~L} 15^{\prime} \mathrm{M}$ receptors alone or in the presence of a fixed concentration of TQS to determine the degree that TQS affected ACh potency (Supplemental Fig. 4; Supplemental Table 2). TQS produced both a 4-fold increase in $I_{\max }$ and a 3-fold decrease in ACh $\mathrm{EC}_{50}$.

Effect of the Number of M15'L Mutants in $\alpha 7$. The data with $\alpha 4 \beta 2$ receptors indicated that the greater the number of L15'M subunits present, the smaller is the amplitude of control ACh responses (Fig. 7B). We expressed RNA coding for wild-type $\alpha 7$ and $\alpha 7 \mathrm{M} 254 \mathrm{~L}$ alone or at varying ratios to determine whether reducing the number of $\mathrm{L}^{\prime} 5^{\prime} \mathrm{M}$ subunits would increase ACh control responses. We saw no significant difference in the ACh control responses over a wide range of subunit ratios (Fig. 8). The potentiating effects of $1 \mu \mathrm{M}$ TQS were less compared with wild-type $\alpha 7$ if the wildtype RNA was less that $50 \%$.

Evaluation of HS and LS $\alpha 4 \beta 2$ Analogs with $\beta 2 L 15 ' M$ in the Binding Sites and Wild-Type $\alpha 4$ or $\beta 2$ in the Accessory Subunit Position. The $\beta 2 \mathrm{~L} 15^{\prime}$ M-6- $\alpha 4$ concatamer was coexpressed with either wild-type $\alpha 4$ or $\beta 2$ to yield LS or HS forms of $\alpha 4 \beta 2$, respectively, with the L15'M mutation in the two $\beta$ subunits that contribute to the ACh binding sites. As expected, the LS analogs had larger $(P<$ 0.05 ) responses to $100 \mu \mathrm{M}$ ACh (Fig. 9A). Also, as expected, due to the low-affinity $\alpha 4-\alpha 4$ binding site, LS receptors had a large increase in response to $100 \mu \mathrm{M}$ ACh compared with $10 \mu \mathrm{M}$ ACh $(P<0.01)$, while the HS analogs showed no increase in response at $100 \mu \mathrm{M}$ compared with $10 \mu \mathrm{M}$ (Fig. 9B). The LS analogs were potentiated about 3-fold by TQS, while the normalized potentiation of HS receptors was 24-fold (Fig. 9C); however, the potentiated LS responses were 
A

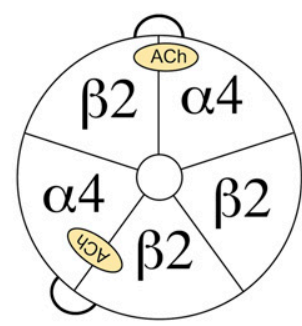

0 mutants

\section{B}

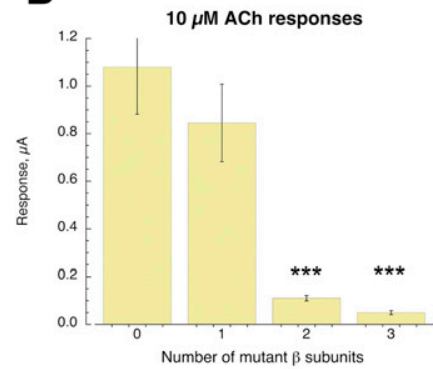

$\mathbf{E}$

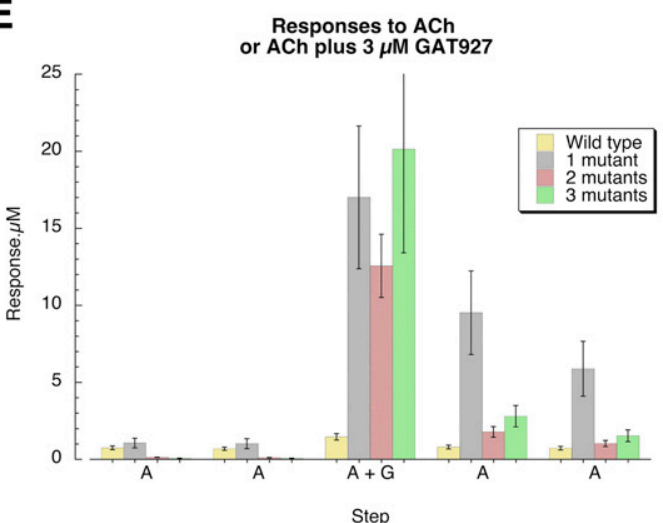

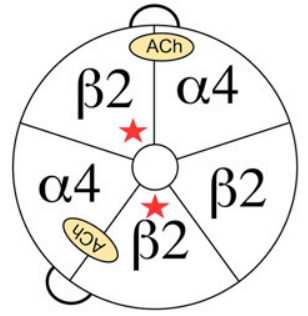

2 mutants

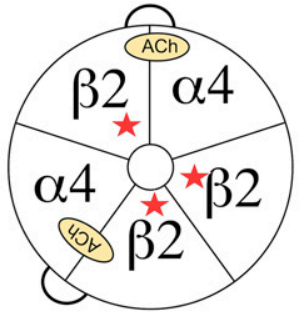

3 mutants

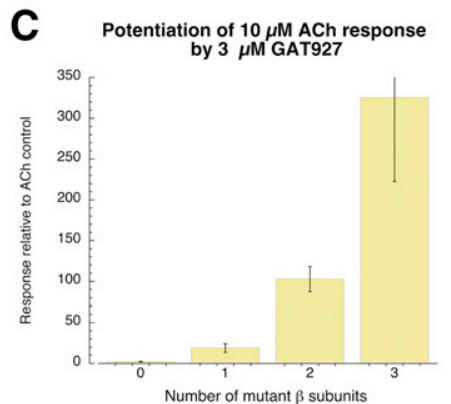

D Responses to $10 \mu \mathrm{M} \mathrm{ACh}+3 \mu \mathrm{M}$ GAT927
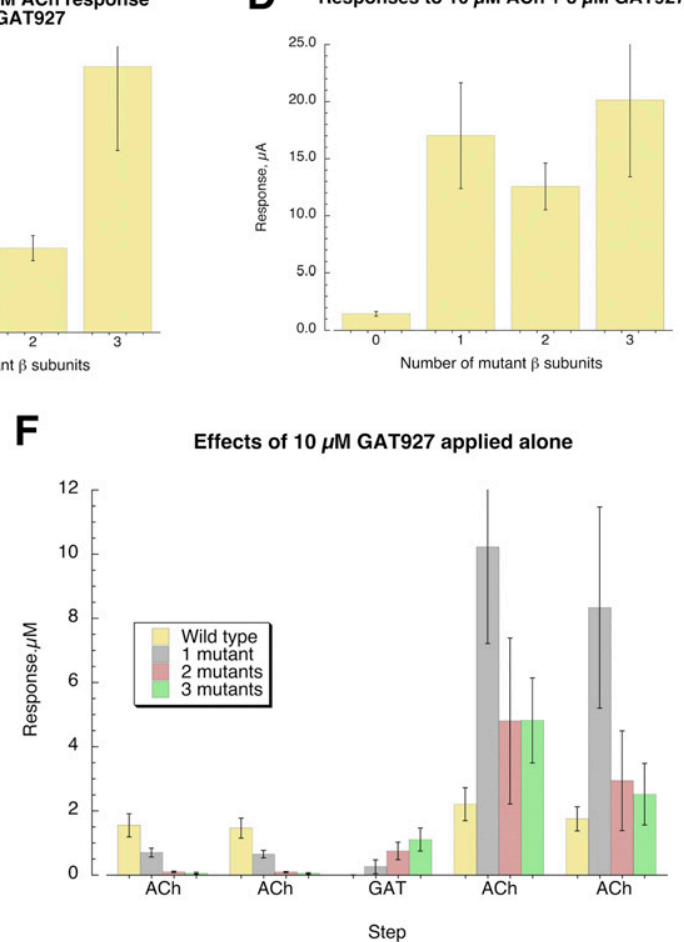

Fig. 7. Effects of GAT927 on HS $\alpha 4 \beta 2$ receptors with different numbers of mutant $\beta$ subunits. (A) The configuration of receptors formed with $\beta 2-6$ - $\alpha 4$ concatamer (Zhou et al., 2003) with or without the $\beta 2 \mathrm{~L} 15^{\prime} \mathrm{M}$ mutation. All receptors had the $\alpha 4: \beta 2$ stoichiometry of $2: 3$, with $0,1,2$, or 3 mutant $\beta$ subunits as indicated. All cells were injected on the same day and recorded the same number of days (7) following injection. (B) The average amplitude of the ACh control responses ( \pm S.E.M., $n=5-7$ ). ACh responses of receptors containing two or three mutant subunits were significantly lower than wildtype receptors $(P<0.001 n=5$ to 6). (C) The potentiation of $30 \mu \mathrm{M}$ ACh responses normalized to the control ACh responses in the same cells. (D) The average ( \pm S.E.M.) amplitude in microamperes of the responses to $30 \mu \mathrm{M}$ ACh coapplied with $3 \mu \mathrm{M}$ GAT927 $(n=5-7)$. While the potentiated responses of all receptors containing any number of mutant $\beta$ subunits were greater than wild-type receptors $(P<0.001)$, there were no significant differences among the receptors containing any number of mutant subunits. (E) Average peak current responses in microamperes of cells through the progress of an experiment, where there were first two control ACh applications followed by a coapplication of $30 \mu \mathrm{M}$ ACh plus $3 \mu \mathrm{M}$ GAT 927, and then two subsequent ACh applications. (F) Average peak current responses in microamperes of cells through the progress of an experiment, where there were first two control ACh applications followed by an application of $10 \mu \mathrm{M}$ GAT 927 alone, and then two subsequent ACh applications.

larger $(P<0.05)$ than the potentiated HS receptors in absolute magnitude (Fig. 9D).

The Relative Potentiation of $\alpha 4 \beta 2 \mathrm{L15}^{\prime} \mathrm{M}$ and $\alpha 7$ by Select PAMs. We determined the relative activity of TQS, GAT927, and other published PAMs for these $\alpha 4 \beta 2 \mathrm{~L} 15^{\prime} \mathrm{M}$ and $\alpha 7$ receptors (Fig. 10). Consistent with the fact that PNU120596 , a very active $\alpha 7 \mathrm{PAM}$, failed to potentiate $\alpha 4 \beta 2 \mathrm{~L} 15^{\prime} \mathrm{M}$ receptors, the data indicate that the structure-activity relationship proscribed by the PAM binding sites in these two receptor types differs remarkably. As noted previously, GAT107 was relatively ineffective on the $\alpha 4 \beta 2 \mathrm{~L} 15^{\prime} \mathrm{M}$ receptors, while GAT927 was much more active $(P<0.001)$ on $\alpha 4 \beta 2 \mathrm{~L} 15^{\prime} \mathrm{M}$ receptors than $\alpha 7$ receptors.

The Effect of $\beta 2 \mathrm{L15}^{\prime} \mathrm{M}$ Coexpression with Alternative $\boldsymbol{\alpha}$ Subunits. Initial studies of neuronal nAChR subtype expression indicated that heteromeric receptors could be formed with various combinations of $\alpha$ and $\beta$ subunits. The $\beta 2$ subunits readily form receptors when coexpressed with $\alpha 2$ or $\alpha 3$ (Boulter et al., 1987; Wada et al., 1988; Papke et al., 1989), and will additionally substitute to a certain degree for the muscle $\beta 1$ subunit (Papke, 2014). TQS-sensitive receptors were formed when $\beta 2 \mathrm{~L} 15^{\prime} \mathrm{M}$ was coexpressed with either $\alpha 2$ or $\alpha 3$ (Fig. 11).

We also coexpressed wild-type $\beta 2$ or $\beta 2 \mathrm{~L} 15^{\prime} \mathrm{M}$ with an $\alpha 2 / \beta 2$ concatamer ( $\beta 2-6-\alpha 2)$ (Papke et al., 2013) that, like the $\beta 2-6$ $\alpha 4$ concatamer in Fig. 7 , would put a single mutant $\beta 2$ in the accessory position. When the receptors contained the single $\beta 2 \mathrm{~L} 15^{\prime} \mathrm{M}$ subunit, coapplication of $10 \mu \mathrm{M}$ TQS produced a 23.7-fold \pm 2.1-fold increase in ACh-evoked responses $(P<0.0001, n=6)$. As was the case with the $\alpha 4$-containing 
$\alpha 7$

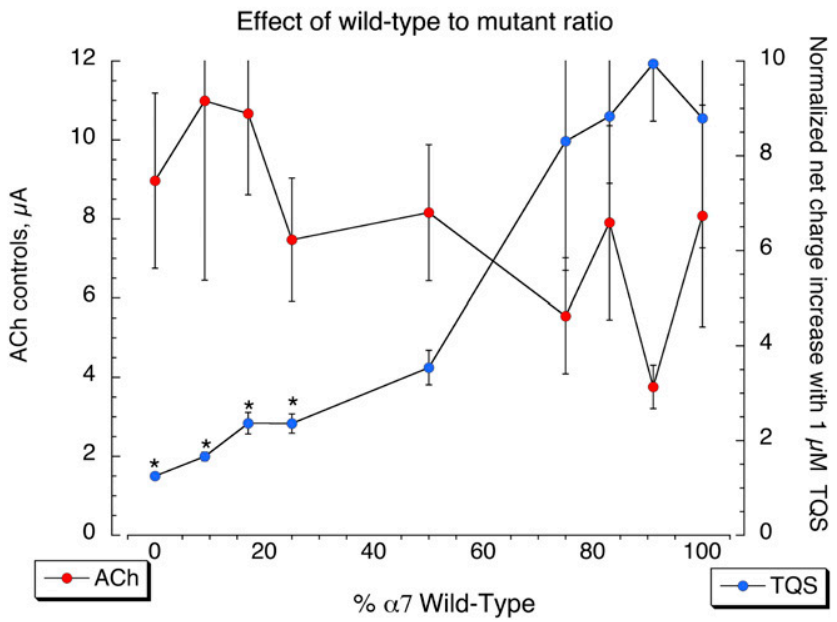

Fig. 8. Effects of mutant number and position. Wild-type $\alpha 7$ and $\alpha 7 \mathrm{M} 254 \mathrm{~L}$ were coexpressed alone or at various ratios such that the total RNA injected was held constant. Plotted are the average peak currents to two initial ACh controls (left axis) and the averaged normalized net charge responses potentiated by the coapplication of $1 \mu \mathrm{M}$ (racemic) TQS (right axis). There were no significant differences among the ACh responses (one-way ANOVA). When the percentage of wild-type RNA was less than $50 \%$, the potentiation was less $(P<0.05)$ than with $100 \% \alpha 7$ wild type.

receptors (Fig. 7), ACh control responses were not significantly reduced with the mutant $\beta 2$ subunit in the accessory position. Responses to $10 \mu \mathrm{M}$ ACh were $120 \pm 11 \mathrm{nA}$ with a wild-type $\beta 2$ $(n=8)$ and $101 \pm 16 \mathrm{nA}$ with $\beta 2 \mathrm{~L} 15^{\prime} \mathrm{M}$.

TQS Sensitivity of Receptors Formed with a $\beta 4 \mathrm{LI5}^{\prime} \mathrm{M}$ Subunit. We made the corresponding L15' M mutation in the alternative neuronal $\beta$ subunit, $\beta 4$ (Duvoisin et al., 1989). As shown in Fig. 12, the receptors formed with any of the three neuronal $\alpha$ subunits tested showed significant potentiation $(P<0.01)$ when ACh was coapplied with $10 \mu \mathrm{M}$ TQS. The relative potentiation was less $(P<0.05)$ than was obtained with $\beta 2 \mathrm{~L} 15^{\prime} \mathrm{M}$ coexpression, although it is interesting to note that there was protracted activation of the receptors formed with $\alpha 4$ and $\beta 4 \mathrm{~L} 15^{\prime} \mathrm{M}$ subunits, similar to what was observed with $\alpha 4$ and $\beta 2 \mathrm{~L} 15^{\prime} \mathrm{M}$ subunits (Fig. 4).

Impact of 15' $^{\prime}$ M Mutations in Other nAChRs. We made the corresponding $\mathrm{L} 15^{\prime} \mathrm{M}$ mutation in the muscle $\beta 1$ subunit; however, the coexpression of $\beta 1 \mathrm{~L} 15^{\prime} \mathrm{M}$ with $\alpha 1$, $\varepsilon$, and $\delta$ resulted in cells that were unresponsive to $\mathrm{ACh}$ alone or coapplied with either TQS or GAT927 (data not shown). However, a number of interesting effects were observed when the L15'M mutation was placed in the other muscle subunits, as summarized in Table 1. Cells were from the same batch of oocytes and tested just 1 day after injection. Surprisingly, ACh control responses were significantly larger than wild-type receptors if the mutation was in the $\gamma$ or $\delta$ subunits. However, for all subunit combinations tested that had the $\mathrm{L} 15^{\prime} \mathrm{M}$ mutation in any subunit, coapplication of $10 \mu \mathrm{M}$ TQS produced a significant reduction in ACh responses (Table 1).

The sequence of $\alpha 9$ and $\alpha 10$ at the $15^{\prime}$ position is unique from $\alpha 7$ and other $\mathrm{nAChRs}$, being a glutamine $(\mathrm{Q})$ rather than either $\mathrm{L}$ or $\mathrm{M}$ (Fig. 1). The expression of $\alpha 9$ in oocytes is relatively inefficient (Verbitsky et al., 2000); however, in our hands $\alpha 9$ expression has been significantly improved with a version of $\alpha 9$ that has been codon optimized for Xenopus (Zakrzewicz et al., 2017). We mutated the $15^{\prime}$ residue in the codon-optimized $\alpha 9$ clone to either L or M. Tested 5 days after injection, cells expressing the wild-type $\alpha 9$ gave peak current responses to $300 \mu \mathrm{M} A C h$ and $3 \mathrm{mM}$ choline of $1.44 \pm 0.53$ and $0.38 \pm 0.11 \mu \mathrm{A}$, respectively $(n=6)$. As expected, responses to $300 \mu \mathrm{M}$ ACh were not increased by coapplication with $10 \mu \mathrm{M}$ TQS. However, there were no detectable responses of either $\alpha 9 \mathrm{Q} 15^{\prime} \mathrm{L}$ or $\alpha 9 \mathrm{Q} 15^{\prime} \mathrm{M}$ to $300 \mu \mathrm{M}$ ACh with or without $10 \mu \mathrm{M}$ TQS (data not shown).

Receptors Containing $\alpha \mathbf{5 L 1 5}$ M. The $\alpha 5$ subunit does not form typical ACh binding sites when coexpressed with other nAChR subunits but will take the position of the accessory subunit when coexpressed with the $\beta 2-6-\alpha 4$ concatamer (Kuryatov et al., 2008). We engineered the L15'M mutation into $\alpha 5$ and coexpressed it with the concatamer. The effects of the mutation in this receptor were rather subtle. Not surprisingly, compared with $\alpha 4(2) \beta 2(2) \alpha 5$ receptors from the same injection set, the ACh control responses of receptors with the $\alpha 5 \mathrm{~L} 15^{\prime} \mathrm{M}$ subunit were significantly smaller $(P<0.05)$ than those with the wild-type $\alpha 5$ (165 $\pm 19 \mathrm{nA}$, compared with $710 \pm 195 \mathrm{nA} ; n=7$ in each group). However, there was only a very slight potentiating effect $\approx 20 \%(P<0.05)$ when ACh was coapplied with $10 \mu \mathrm{M}$ TQS. We then tested the $\alpha 4(2) \beta$ 2 (2) $\alpha 5 \mathrm{~L} 15^{\prime} \mathrm{M}$ receptors with a coapplication of $30 \mu \mathrm{M}$ GAT927 and noted that the peak currents of the coapplication responses were $3.73 \pm 0.66$ that of the ACh controls $(n=6$; data not shown). However, it should be noted that this relatively small but significant effect $(P<0.05)$ did no more than bring the level of the mutant's potentiated responses up to the level of the ACh controls of the receptors without the L 15 ' M mutation in the $\alpha 5$ subunit.

$\alpha 7$ PAM Binding Sites in $\alpha 4 \beta 2 L 15$ 'M Receptors. Currently, the best available models of $\alpha 7$ structure (Li et al., 2011; Nemecz and Taylor, 2011) are homology models based on mutant forms of the ACh binding protein that do not include any of the transmembrane or intracellular domains. Therefore, attempts to model the PAM binding site have relied on relatively low-resolution structures such as those extrapolated from a Torpedo nAChR cryomicroscopy density map (Newcombe et al., 2018). Instead, we analyzed mutation data in the context of experimental high-resolution structural information (Fig. 13A), where side chain positions are not ambiguous (Walsh et al., 2018). As predicted by the sequence data (Fig. 1), the L/M site (residue 254 in $\alpha 7$ ) is toward the extracellular end of the pore-forming TM2, while the alternative site, A226, previously shown to be important for PNU-120596 potentiation of $\alpha 7$, is deep within the transmembrane region on the first transmembrane domain (Young et al., 2008). Also shown in Figure 13A are the structures of PNU-120596 and the TQS isomers at the same scale. We attempted to dock the (-)-TQS molecule into this structure. However, docking to the cryo-EM structure of the $\alpha 4 \beta 2$ receptor in complex with the agonist nicotine did not reveal a high-affinity binding site for TQS. This result suggests that the receptor requires a conformational change to create such a pocket and bind TQS with high affinity. Additionally, we hypothesize that the L $15^{\prime} \mathrm{M}$ mutation is likely to engender a specific reorganization that is not represented in the cryo-EM structure. Moreover, the structure shown is presumed to represent a desensitized state (Walsh et al., 2018), and a primary effect of the binding of the TQS analogs would be to destabilize desensitized conformations. 
A $100 \mu \mathrm{M}$ ACh responses

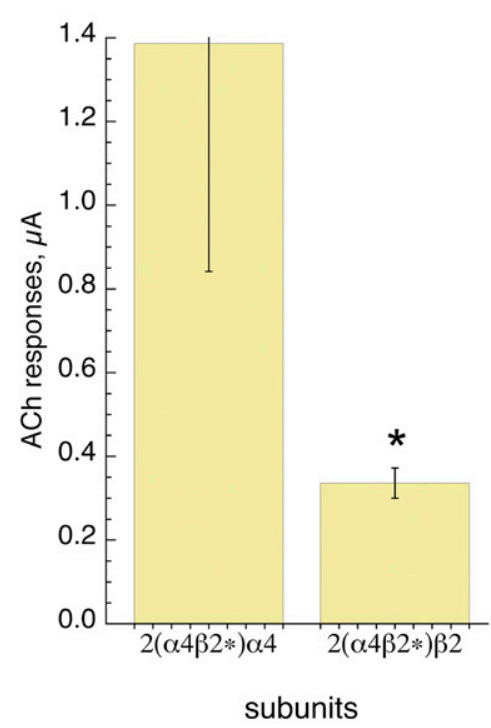

C Potentiation of $100 \mu \mathrm{M}$ ACh by $10 \mu \mathrm{M}$ TQS

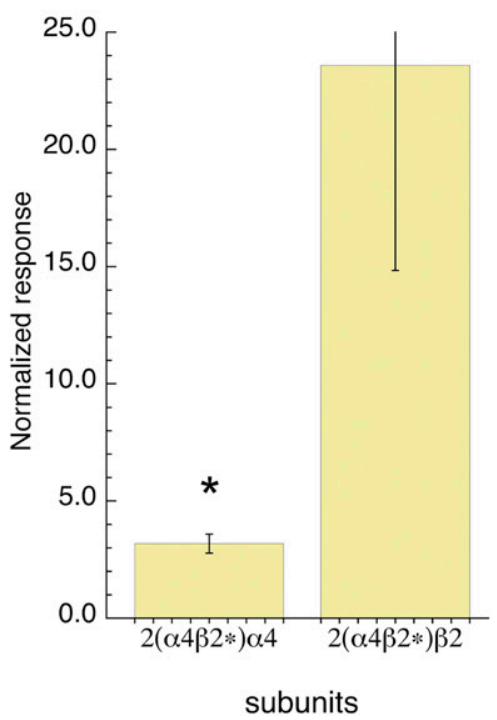

B $100 \mu \mathrm{M}$ ACh relative to $10 \mu \mathrm{M}$ ACh Peak currents

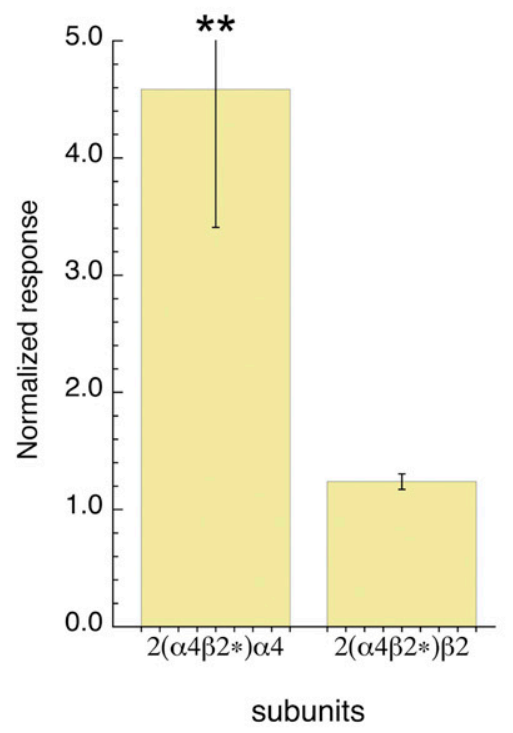

D
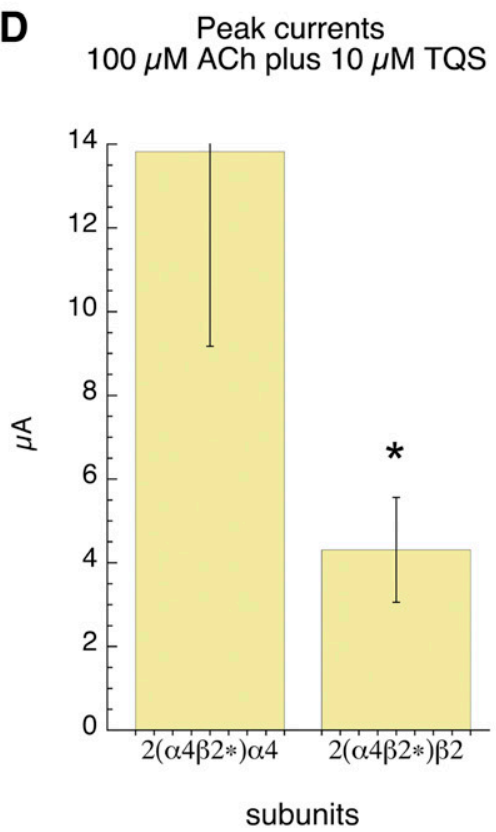

Fig. 9. Evaluation of HS and LS $\alpha 4 \beta 2$ analogs with $\beta 2 \mathrm{~L} 15$ ' $\mathrm{M}$ in the binding sites and wild-type $\alpha 4$ or $\beta 2$ in the accessory subunit position. (A) The average responses to $100 \mu \mathrm{M}$ ACh. Responses of receptors with a $\beta 2$ subunit in the accessory position were smaller than those with an $\alpha 4$ subunit $(P<0.05)$. (B) Responses to $100 \mu \mathrm{M}$ ACh relative to $10 \mu \mathrm{M}$ ACh in the same cells. Responses of receptors with an $\alpha 4$ subunit in the accessory position to $100 \mu \mathrm{M}$ ACh were significantly larger than their responses to $10 \mu \mathrm{M}$ ACh $(P<0.01)$, while those with an accessory $\beta 2$ subunit were not increased. (C) The normalized responses to $100 \mu \mathrm{M}$ ACh $\pm 10 \mu \mathrm{M}$ TQS. Responses of receptors with a $\beta 2$ subunit in the accessory position were significantly larger than those with an $\alpha 4$ subunit in the accessory position $(P>$ 0.05). (D) Potentiated responses to $100 \mu \mathrm{M}$ ACh plus $10 \mu \mathrm{M}$ TQS in microamperes. In terms of absolute magnitude, responses of receptors with a $\beta 2$ subunit in the accessory position were significantly smaller than those with an $\alpha 4$ subunit in the accessory position $(P>0.05)$.
PNU-120596 and TQS are roughly the same size, potentially large enough to span the distance between L255 and A227 ( $\beta 2$ numbering). The original data identifying these residues (Young et al., 2008) was based only on the use of PNU-120596. In $\beta 2 \mathrm{~L} 15^{\prime} \mathrm{M}$, both of these residues are the same as in $\alpha 7$ wild type, but the $\alpha 4 \beta 2 \mathrm{~L} 15^{\prime} \mathrm{M}$ receptors are insensitive to PNU-120596. Therefore, we tested whether L254 and A226 residues differentially affected TQS and PNU120596 activity in $\alpha 7$ (Fig. 13B). Our data confirmed that both of these residues profoundly reduce the potentiating activity of PNU-120596 but indicated that TQS potentiation is insensitive to the A226D mutation. These data suggest that the binding or coupling mechanisms for these two PAMs differ in $\alpha 7$ and that some structural elements unique to the neuronal $\beta$ mutants are permissive for TQS potentiation but restrict PNU-120596 from being active, and account for the differing structure-activity relationships shown in Fig. 10. Of course, since PAM binding and/or the coupling of binding to facilitated channel activation are likely to involve interactions between subunits, crucial structural elements may also be present in the complementary subunits at the subunitsubunit interfaces.

\section{Discussion}

The $\alpha 7$ nAChR has an intrinsically low probability of opening $\left(P_{\text {open }}\right)$ immediately after a large jump in ACh concentration or in the sustained presence of an agonist (Williams et al., 2012). This is largely due to a form of desensitization that is unique to $\alpha 7$ and induced by high levels of ACh binding site occupancy (Papke and Porter Papke, 2002; Uteshev et al., 2002). This special form of 


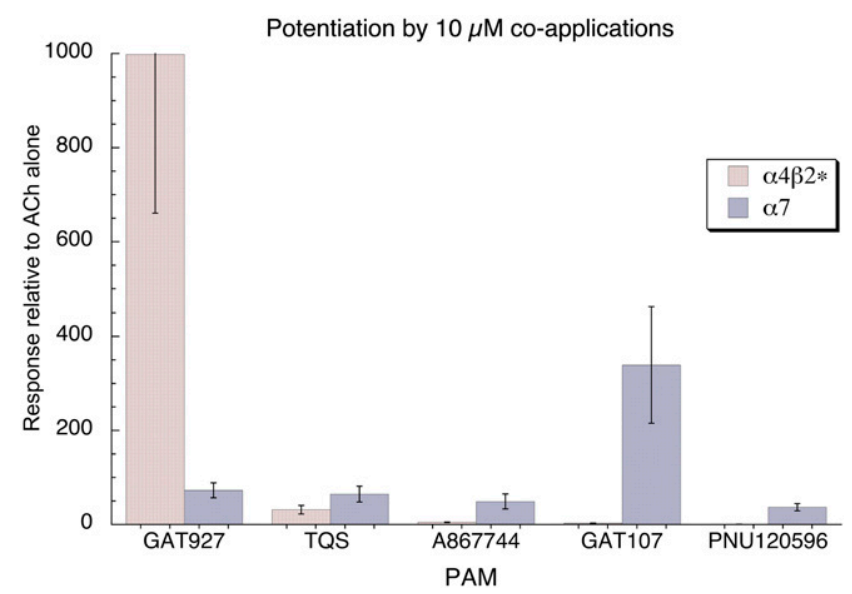

Fig. 10. Comparison of the potentiation of $\alpha 4 \beta 2 \mathrm{~L} 15^{\prime} \mathrm{M}$ receptors and $\alpha 7$ by TQS and GAT927 and other published PAMs. Data are the averaged responses to ACh (30 $\mu \mathrm{M}$ for $\alpha 4 \beta 2 \mathrm{~L} 15^{\prime} \mathrm{M}$ receptors and $60 \mu \mathrm{M}$ for $\left.\alpha 7\right)$ coapplied with the indicated PAM at $10 \mu \mathrm{M}$, relative to the responses to $\mathrm{ACh}$ alone.

desensitization can be destabilized by type II PAMs (Grønlien et al., 2007), which are selective for $\alpha 7$ wild-type receptors (Williams et al., 2011a,b). In contrast, muscle-type and heteromeric neuronal nAChRs have a very high $P_{\text {open }}$ immediately after a large jump in $\mathrm{ACh}$ concentration ( $\mathrm{Li}$ and Steinbach, 2010), but then transition to an equilibrium condition that favors desensitized conformations (Campling et al., 2013). Studies of mutants and chimeras between $\alpha 7$ and the structurally related, but PAM-insensitive, homomeric 5HT3A receptor identified several residues within the $\alpha 7$ transmembrane domain (Fig. 1) that were required for the activity of the PAM PNU-120596 (Bertrand et al., 2008; Young et al., 2008). It has been proposed that these residues define a binding site that accommodates the PAM (Newcombe et al., 2018), although it is equally possible that at least some of these residues were required not for PAM binding per se but for the coupling between the agonist binding sites and the channel gating domains.

The type II PAMs such as PNU-120596 and TQS are distinguished from other less efficacious type I PAMs because of their ability to reverse receptor desensitization (Grønlien et al., 2007). Interestingly, their effects appear to produce extremely large increases in the $P_{\text {open }}$ of a relatively small percentage of channels at any given time (Williams et al., 2011a; Andersen et al., 2016). The relationship between
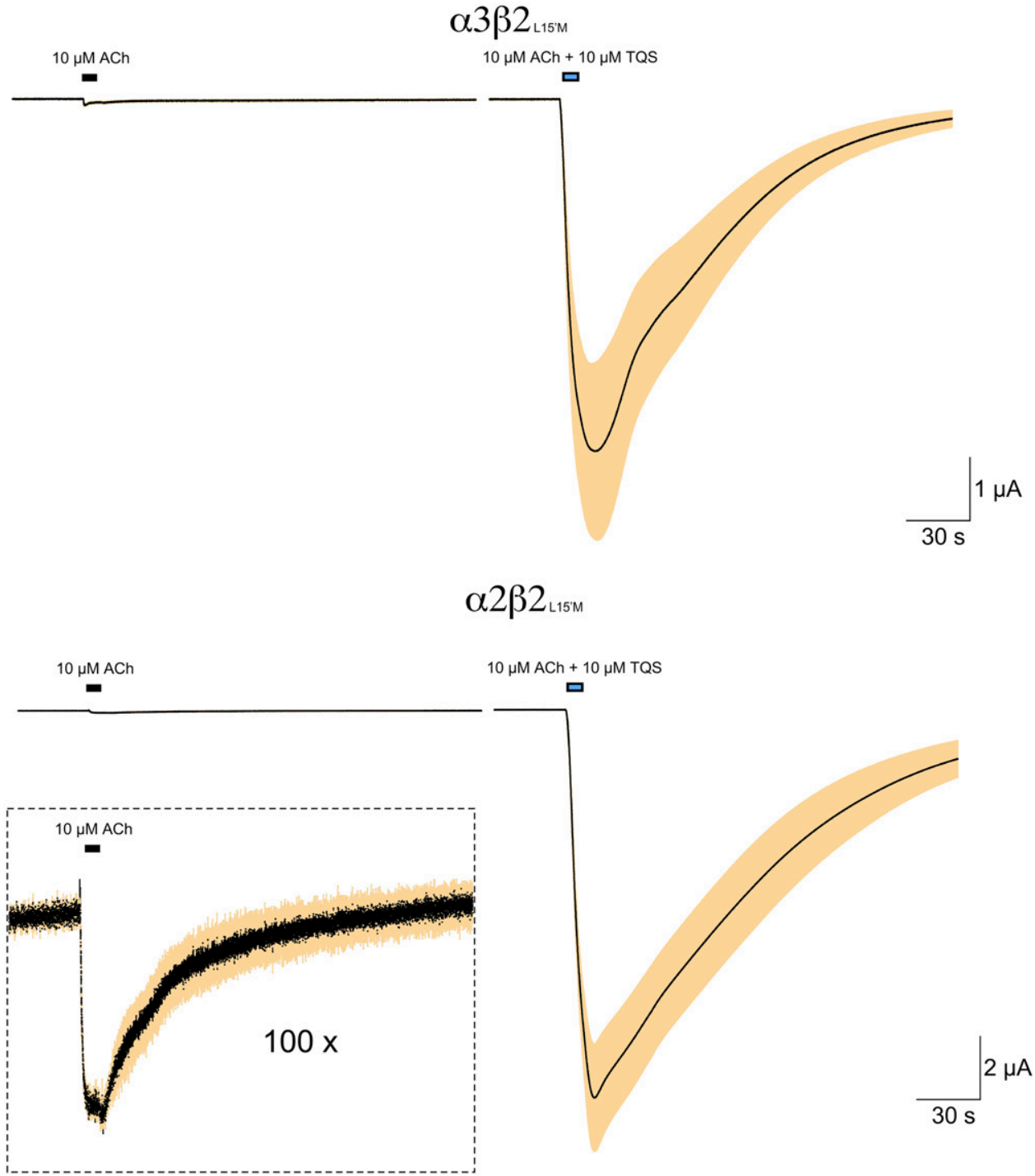

Fig. 11. The coexpression of $\beta 2 \mathrm{~L} 15^{\prime} \mathrm{M}$ with the alternative $\alpha$ subunits, $\alpha 2$ or $\alpha 3$. Shown are the averaged raw data responses of 4-6 cells, normalized to $100 \mu \mathrm{M}$ ACh control responses in the same cell. 


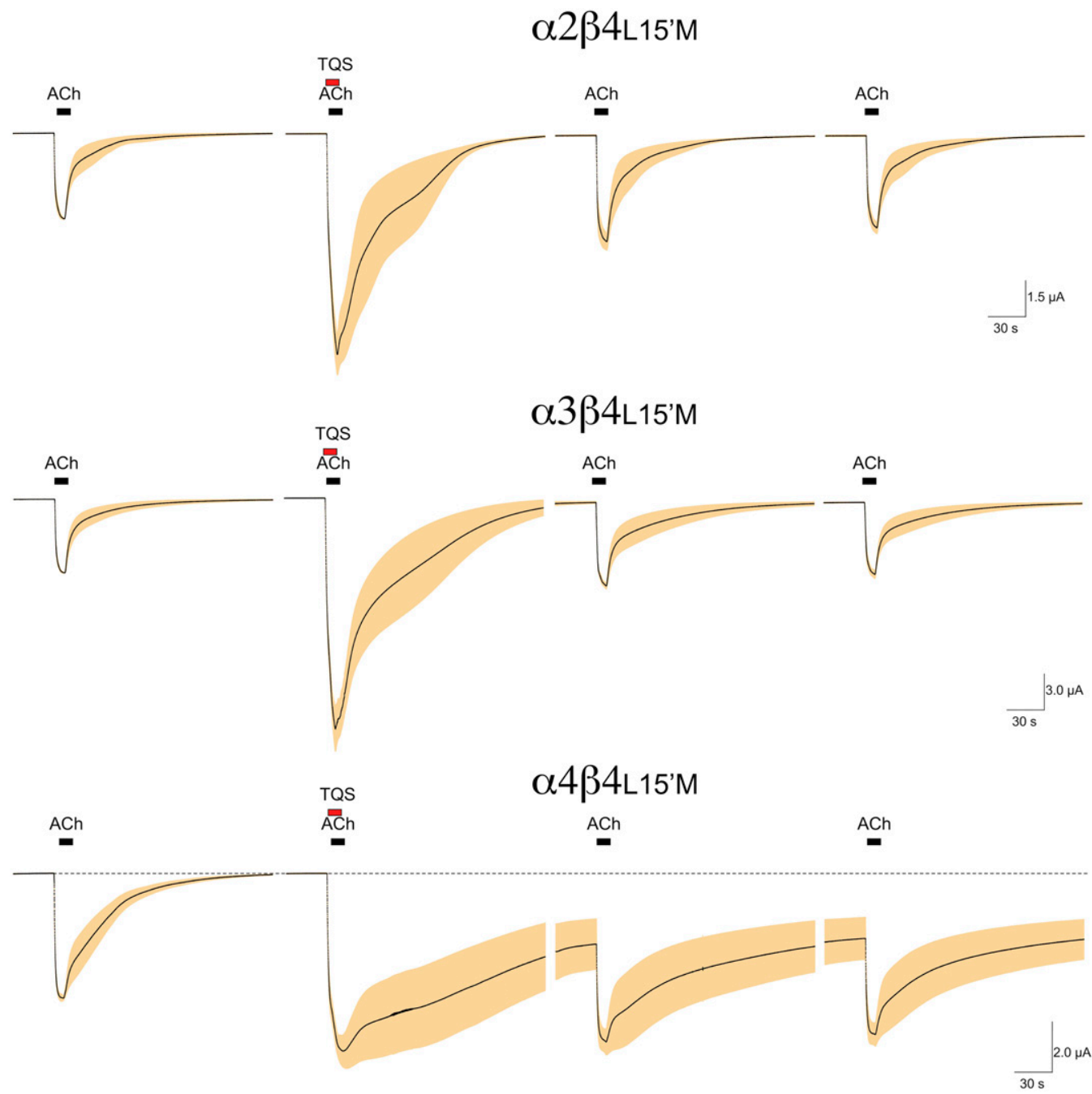

Fig. 12. The coexpression of $\beta 4 \mathrm{~L} 15^{\prime} \mathrm{M}$ with alternative $\alpha$ subunits. Shown are the averaged raw data responses of $4-6$ cells, normalized to $100 \mu \mathrm{M}$ ACh control responses in the same cells. TQS was coapplied at a concentration of $10 \mu \mathrm{M}$.

macroscopic and single-channel current is dependent on three factors: the total number of receptors contributing to the response $(N), P_{\text {open }}$, and the single-channel conductance $(\gamma)$. When studying the currents of a single channel, by definition, $N=1$, and for such single-channel currents in the presence of a PAM such as PNU-120596 or an ago-PAM such as GAT107, the increase in $P_{\text {open }}$ is on the order of 100,000 or more, while the macroscopic effect of such PAMs is perhaps 1000-fold lower, suggesting a proportionally smaller number of receptors contributing to the macroscopic (whole cell) response (Williams et al., 2011a).

Examination of the putative PAM binding domain in $\alpha 7$ highlights the unique methionine in the $15^{\prime}$ position of TM2 (Fig. 1), one of the two most important residues for PAM activity identified by site-directed mutations (Young et al., 2008). This position could be mutated in $\alpha 7$ to $\mathrm{L}$ without apparent change in function, except in regard to PAM activity. We see neither a change in amplitude nor kinetics of macroscopic current in $\alpha 7 \mathrm{M} 254 \mathrm{~L}$ compared with wild type. In contrast, when the reverse mutation was made in $\alpha 4 \beta 2$ receptors, we saw large decreases in the control responses to ACh when one or more subunits in the ACh binding sites contained a $15^{\prime} \mathrm{M}$ subunit (Figs. 3 and 7 ). In the case of the $\alpha 4 \mathrm{~L} 15^{\prime} \mathrm{M}$ mutants, this was the only effect we observed (Fig. 3); however, when the mutation was present in $\beta 2$ subunits we saw that receptors became sensitive to a number of PAMs previously reported to be selective for $\alpha 7$ (Figs. 5-7).

As noted previously, macroscopic responses are determined by three factors, $N, P_{\text {open }}$, and $\gamma$. It is plausible that a $15^{\prime} \mathrm{M}$ residue in subunits that form agonist binding sites could affect receptor assembly or trafficking. However, it seems more likely that it affects the coupling of agonist binding to channel activation, and hence $P_{\text {open }}$, especially since PAMs can bring

TABLE 1

Effects of L15'M mutation (*) in muscle-type nAChR ACh controls compared with wild type, unpaired $t$ tests, $* P<0.05$. ACh plus TQS compared with ACh alone, paired $t$ tests, ${ }^{\dagger} P<0.05$; ${ }^{\dagger \dagger} P<0.01$; ${ }^{\dagger \dagger} P<$ 0.001 . Peak current responses are in microamperes. NA, not available.

\begin{tabular}{lccc}
\hline Subunit & $30 \mu \mathrm{M} \mathrm{ACh}$ & ACh $+10 \mu \mathrm{M}$ TQS & $N$ \\
\hline$\alpha 1 \beta 1 \varepsilon \delta$ & $0.31 \pm 0.19$ & $0.17 \pm 0.12$ & 7 \\
$\alpha 1^{*} \beta 1 \varepsilon \delta$ & $0.028 \pm 0.005$ & $0.013 \pm 0.002^{\dagger \dagger \dagger}$ & 8 \\
$\alpha 1 \beta 1 \varepsilon^{*} \delta$ & $1.05 \pm 0.34$ & $0.36 \pm 0.12^{\dagger}$ & 8 \\
$\alpha 1 \beta 1 \gamma^{*} \delta$ & $8.70 \pm 1.88^{*}$ & $6.68 \pm 2.09^{\dagger \dagger}$ & 8 \\
$\alpha 1 \beta 1 \varepsilon \delta^{*}$ & $1.34 \pm 0.41^{*}$ & $0.68 \pm 0.23^{\dagger}$ & 7 \\
$\alpha 1 \beta 1 \varepsilon^{*} \delta^{*}$ & $8.79 \pm 1.92^{*}$ & $5.8 \pm 1.5^{\dagger \dagger \dagger}$ & 8 \\
$\alpha 1 \beta 1^{*} \varepsilon \delta$ & $\mathrm{NA}$ & $\mathrm{NA}$ & \\
\hline
\end{tabular}


A

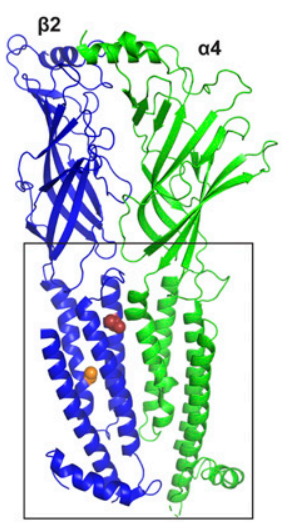

B

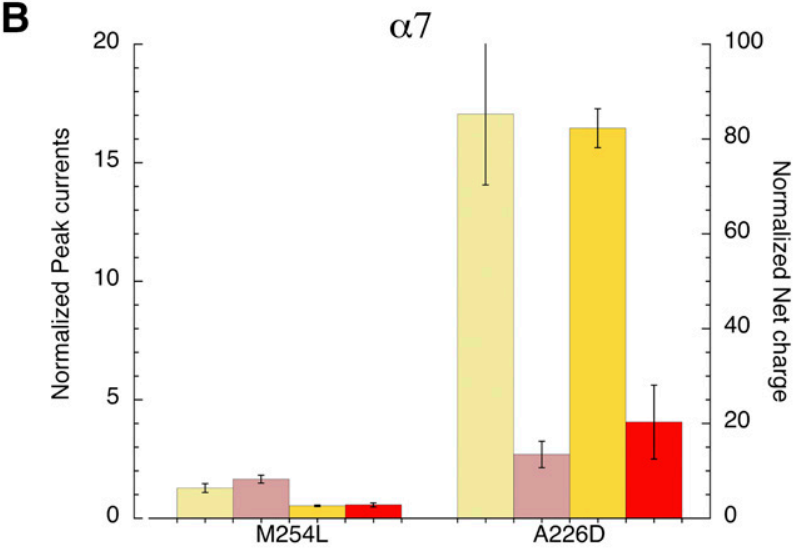

$\alpha 4 \beta 2$

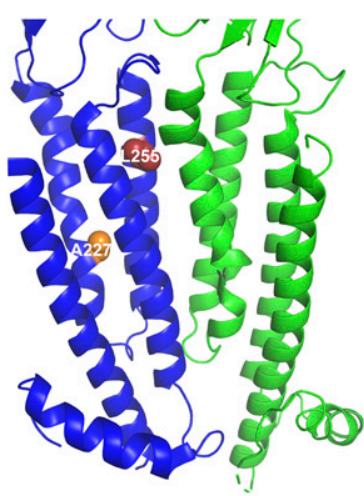

TQS (-) TQS (+)
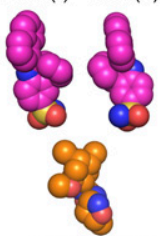

PNU 120596
Mutant

TQS Peak

PNU peak

Fig. 13. Location and differential effects of residues affecting PAM activity in $\alpha 4 \beta 2$ and $\alpha 7$. (A) Left, a $\beta 2-\alpha 4$ interface from the heteropentameric $\alpha 4 \beta 2$ receptor (Protein Data Bank: $6 \mathrm{CNJ}$ ) is shown ( $\beta 2$ is in blue and $\alpha 4$ is in green). The $15^{\prime}$ residue of M2 implicated in binding to TQS and PNU-120596 is shown as red spheres, while A227 (associated with the potentiating effects of PNU-120596) is shown as orange spheres. Right, the active (-) isomer and inactive (+) isomers of TQS are shown as magenta spheres, and PNU-120596 (PNU) is shown as bronze spheres; these are shown to scale with the transmembrane regions in the center. (B) The differential effects of the M254L and A226D mutations in $\alpha 7$ on potentiation by PNU-120596 and TQS.

up the currents in receptors containing multiple mutant subunits to levels equivalent to or greater than wild-type receptors (i.e., compensating for decreased control ACh response). Simply because methionine is much more flexible than leucine, the mutation could result in a less stable interface among the transmembrane helices at this position, destabilizing the allosteric network important for gating. The fact that the decreases in macroscopic currents require the presence of the mutation in an agonist binding subunit would also seem to make an effect on gating most likely. However, the methionine side chain is also longer than that of leucine, and by steric repulsion may push the apical portion of M2 more toward the pore axis, making it harder to fully open the channel, which would suggest a possible decrease in $\gamma$.

The effects of the L15'M mutation seem to be consistent for all of the common functional neuronal $\alpha / \beta$ heteromeric receptors (Figs. 11 and 12), where $\alpha$ is $\alpha 2, \alpha 3$, or $\alpha 4$, and $\beta$ is $\beta 2$ or $\beta 4$. As in $\alpha 7$ receptors, it is reasonable to hypothesize

that the PAM's effect on these receptors enables a bursting state coupled to what would otherwise be a desensitized form of the receptor. This, as well as a direct determination of whether there are changes in single-channel conductance, will be a focus of future single-channel studies.

The $\beta 2 \mathrm{~L} 15^{\prime} \mathrm{M}$ subunit itself may prove to be a useful experimental tool. However, while in our in vitro system we can limit the expression of the $\beta 2$ mutant to the accessory subunit and thus avoid the effect of reducing $P_{\text {open }}$ in the absence of a PAM, in vivo the mutation would necessarily be in all $\beta$ subunits. Therefore, the expression of $\beta 2 \mathrm{~L} 15^{\prime} \mathrm{M}$ in $\beta 2$ knockout animals would allow for only partial rescue of function. However, the delivery of a PAM, especially one as efficacious as GAT927, would perhaps produce a significant gain of function, amplifying the function of $\beta 2$-containing receptors for behaviors such as nicotine self-administration. Additionally, the identification of PAM-sensitive heteromeric nAChRs provides new opportunities to study the basis for $\alpha 7$ $\mathrm{nAChR}$ receptor dynamics in a system that is arguably both more simple and more complex.

The $\alpha 7 \mathrm{nAChRs}$ have long been considered interesting targets for therapeutics, beginning with the identification of GTS-21 as a selective partial agonist (Papke et al., 1996(Meyer et al., 1998)). Although no $\alpha 7$ agonists have passed the rigors of clinical trials, their utility has been supported by many preclinical studies (Leiser et al., 2009; Wallace et al., 2011; Prickaerts et al., 2012; Bertrand et al., 2015; Pieschl et al., 2017). More recently, with the discovery of $\alpha 7$ 's role in CAPs (Pavlov et al., 2007; Rosas-Ballina et al., 2009; Rosas-Ballina and Tracey, 2009), $\alpha 7$ drugs continue to be investigated as alternative analgetic agents for inflammatory and neuropathic pain (Bagdas et al., 2018). The discovery of $\alpha 7$ PAMs have further enlarged these potentially important therapeutic directions. Interestingly, although the activity on the immune cells that mediate CAPs does not seem to require $\alpha 7$ channel activation (Papke et al., 2015), the $\alpha 7$ PAMs PNU-120596 (Freitas et al., 2013) and TQS (Abbas et al., 2017) have both been shown to have CAP activity.

Many challenges remain in understanding $\alpha 7$ as a therapeutic target, including the definition of its complex conformational dynamics and how those dynamics may couple to intracellular signal transduction (Kabbani and Nichols, 2018). The structure-activity relationship for PAM activity on $\alpha 4 \beta 2 \mathrm{~L} 15^{\prime} \mathrm{M}$ receptors is quite different from $\alpha 7$, based on both the inactivity of some PAMs (e.g., PNU-120596) on $\alpha 4 \beta 2 \mathrm{~L} 15^{\prime} \mathrm{M}$ receptors and the relative activity of TQS analogs that are active on both. While there are at present no actual $\alpha 7$ structures that incorporate the putative PAM binding site, the cryo-EM structure of $\alpha 4 \beta 2$ receptors offers a promising new approach for studying the allosteric modulation of nAChR, especially if new structures can be generated of $\alpha 4 \beta 2$ receptors including the $15^{\prime}$ mutation with TQS in situ.

Additionally, our studies refute the hypothesis that PAMs such as TQS were selective for $\alpha 7$ because they reversed the form of desensitization that was a unique limiting factor to $\alpha 7$ mediated currents (Williams et al., 2012) and suggest that instead they can reverse forms of desensitization common to all nAChRs. The phenomenon of desensitization, since it was first described by Katz and Thesleff (1957) for muscle-type nAChRs, has been an elephant in the room for all subsequent studies of nAChRs. The role of $\alpha 4 \beta 2$ desensitization in reinforcing effects of nicotine remains a contentious subject (Picciotto et al., 2008). By identifying a new tool for studying 
$\alpha 4 \beta 2$ desensitization, we may ultimately gain more understanding of nicotine addiction, which in the case of cigarette smoking is the single most preventable cause of death in many countries.

\section{Acknowledgments}

The authors thank Lu Wenchi Corrie for care and diligence in the performance of the oocyte experiments. K.A.A. acknowledges the National Science Foundation and the University of Florida for funding of the purchase of the X-ray equipment.

\section{Authorship Contributions}

Participated in research design: Stokes, Papke.

Conducted experiments: Stokes, Abboud.

Contributed new reagents or analytic tools: Garai, Kulkarni, Cantwell, Noviello, Thakur.

Performed data analysis: Papke.

Wrote or contributed to the writing of the manuscript: Stokes, Noviello, Thakur, Hibbs, Horenstein, Papke.

\section{References}

Abbas M, Alzarea S, Papke RL, and Rahman S (2017) The $\alpha 7$ nicotinic acetylcholine receptor positive allosteric modulator attenuates lipopolysaccharide-induced activation of hippocampal $I \kappa B$ and $C D 11 b$ gene expression in mice. Drug Discov Ther 11:206-211.

Akabas MH, Kaufmann C, Archdeacon P, and Karlin A (1994) Identification of acetylcholine receptor channel-lining residues in the entire M2 segment of the $\alpha$ subunit. Neuron 13:919-927.

Andersen ND, Nielsen BE, Corradi J, Tolosa MF, Feuerbach D, Arias HR, and Bouzat C (2016) Exploring the positive allosteric modulation of human $\alpha 7$ nicotinic receptors from a single-channel perspective. Neuropharmacology 107: 189-200.

Bagdas D, Gurun MS, Flood P, Papke RL, and Damaj MI (2018) New insights on neuronal nicotinic acetylcholine receptors as targets for pain and inflammation a focus on $\alpha 7$ nAChRs. Curr Neuropharmacol 16:415-425.

Bagdas D, Wilkerson JL, Kulkarni A, Toma W, AlSharari S, Gul Z, Lichtman AH, Papke RL, Thakur GA, and Damaj MI (2016) The $\alpha 7$ nicotinic receptor dual allosteric agonist and positive allosteric modulator GAT107 reverses nociception in mouse models of inflammatory and neuropathic pain. $\mathrm{Br} J$ Pharmacol 173 2506-2520.

Bertrand D, Bertrand S, Cassar S, Gubbins E, Li J, and Gopalakrishnan M (2008) Positive allosteric modulation of the $\alpha 7$ nicotinic acetylcholine receptor: ligand interactions with distinct binding sites and evidence for a prominent role of the M2-M3 segment. Mol Pharmacol 74:1407-1416.

Bertrand D, Lee CH, Flood D, Marger F, and Donnelly-Roberts D (2015) Therapeutic potential of $\alpha 7$ nicotinic acetylcholine receptors. Pharmacol Rev 67:1025-1073.

Boulter J, Connolly J, Deneris E, Goldman D, Heinemann S, and Patrick J (1987) Functional expression of two neuronal nicotinic acetylcholine receptors from cDNA clones identifies a gene family. Proc Natl Acad Sci USA 84:7763-7767.

Campling BG, Kuryatov A, and Lindstrom J (2013) Acute activation, desensitization and smoldering activation of human acetylcholine receptors. PLoS One 8:e79653.

Clarke PBS, Schwartz RD, Paul SM, Pert CB, and Pert A (1985) Nicotinic binding in rat brain: autoradiographic comparison of $\left[{ }^{3} \mathrm{H}\right]$ acetylcholine, $\left[{ }^{3} \mathrm{H}\right]$ nicotine, and $\left[{ }^{125} \mathrm{I}\right]-\alpha$-bungarotoxin. J Neurosci 5:1307-1315.

Duvoisin RM, Deneris ES, Patrick J, and Heinemann S (1989) The functional diversity of the neuronal nicotinic acetylcholine receptors is increased by a novel subunit: $\beta 4$. Neuron 3:487-496.

Faghih R, Gopalakrishnan SM, Gronlien JH, Malysz J, Briggs CA, Wetterstrand C, Ween H, Curtis MP, Sarris KA, Gfesser GA, et al. (2009) Discovery of 4-(5-(4chlorophenyl)-2-methyl-3-propionyl-1 $H$-pyrrol-1-yl)benzenesulfonamide (A867744 ) as a novel positive allosteric modulator of the $\alpha 7$ nicotinic acetylcholine receptor. J Med Chem 52:3377-3384.

Freitas K, Ghosh S, Ivy Carroll F, Lichtman AH, and Imad Damaj M (2013) Effects of $\alpha 7$ positive allosteric modulators in murine inflammatory and chronic neuropathic pain models. Neuropharmacology 65:156-164.

Garai S, Raja KS, Papke RL, Deschamps JR, Damaj MI, and Thakur GA (2018) B973, a novel $\alpha 7 \mathrm{nAChR}$ ago-PAM: racemic and asymmetric synthesis, electrophysiological studies, and in vivo evaluation. ACS Med Chem Lett 9:1144-1148.

Gill JK, Dhankher P, Sheppard TD, Sher E, and Millar NS (2012) A series of $\alpha 7$ nicotinic acetylcholine receptor allosteric modulators with close chemical similarity but diverse pharmacological properties. Mol Pharmacol 81:710-718.

Gill JK, Savolainen M, Young GT, Zwart R, Sher E, and Millar NS (2011) Agonist activation of $\alpha 7$ nicotinic acetylcholine receptors via an allosteric transmembrane site. Proc Natl Acad Sci USA 108:5867-5872.

Gill-Thind JK, Dhankher P, D’Oyley JM, Sheppard TD, and Millar NS (2015) Structurally similar allosteric modulators of $\alpha 7$ nicotinic acetylcholine receptors exhibit five distinct pharmacological effects. J Biol Chem 290:3552-3562.

Grønlien JH, Håkerud M, Ween H, Thorin-Hagene K, Briggs CA, Gopalakrishnan M, and Malysz J (2007) Distinct profiles of $\alpha 7 \mathrm{nAChR}$ positive allosteric modulation revealed by structurally diverse chemotypes. Mol Pharmacol 72:715-724.

Gulsevin A, Papke RL, Stokes C, Garai S, Thakur GA, Quadri M, and Horenstein NA (2019) Allosteric agonism of $\alpha 7$ nicotinic acetylcholine receptors: receptor modulation outside the orthosteric site. Mol Pharmacol 95:606-614.
Halevi S, Yassin L, Eshel M, Sala F, Sala S, Criado M, and Treinin M (2003) Conservation within the RIC-3 gene family. Effectors of mammalian nicotinic acetylcholine receptor expression. J Biol Chem 278:34411-34417.

Harpsøe K, Ahring PK, Christensen JK, Jensen ML, Peters D, and Balle T (2011) Unraveling the high- and low-sensitivity agonist responses of nicotinic acetylcholine receptors. J Neurosci 31:10759-10766.

Horenstein NA, Papke RL, Kulkarni AR, Chaturbhuj GU, Stokes C, Manther K, and Thakur GA (2016) Critical molecular determinants of $\alpha 7$ nicotinic acetylcholine receptor allosteric activation: separation of direct allosteric activation and positive allosteric modulation. J Biol Chem 291:5049-5067.

Hurst RS, Hajós M, Raggenbass M, Wall TM, Higdon NR, Lawson JA, RutherfordRoot KL, Berkenpas MB, Hoffmann WE, Piotrowski DW, et al. (2005) A novel positive allosteric modulator of the $\alpha 7$ neuronal nicotinic acetylcholine receptor: in vitro and in vivo characterization. $J$ Neurosci 25:4396-4405.

Kabbani N and Nichols RA (2018) Beyond the channel: metabotropic signaling by nicotinic receptors. Trends Pharmacol Sci 39:354-366.

Katz B and Thesleff S (1957) A study of the desensitization produced by acetylcholine at the motor end-plate. J Physiol 138:63-80.

Kulkarni AR and Thakur GA (2013) Microwave-assisted expeditious and efficient synthesis of cyclopentene ring-fused tetrahydroquinoline derivatives using threecomponent povarov reaction. Tetrahedron Lett 54:6592-6595.

Kuryatov A, Onksen J, and Lindstrom J (2008) Roles of accessory subunits in $\alpha 4 \beta 2^{*}$ nicotinic receptors. Mol Pharmacol 74:132-143.

Leiser SC, Bowlby MR, Comery TA, and Dunlop J (2009) A cog in cognition: how the $\alpha 7$ nicotinic acetylcholine receptor is geared towards improving cognitive deficits. Pharmacol Ther 122:302-311.

Levin ED and Rezvani AH (2000) Development of nicotinic drug therapy for cognitive disorders. Eur J Pharmacol 393:141-146.

Li P and Steinbach JH (2010) The neuronal nicotinic $\alpha 4 \beta 2$ receptor has a high maximal probability of being open. Br J Pharmacol 160:1906-1915.

Li SX, Huang S, Bren N, Noridomi K, Dellisanti CD, Sine SM, and Chen L (2011) Ligand-binding domain of an $\alpha 7$-nicotinic receptor chimera and its complex with agonist. Nat Neurosci 14:1253-1259.

Lucero LM, Weltzin MM, Eaton JB, Cooper JF, Lindstrom JM, Lukas RJ, and Whiteaker $\mathrm{P}(2016)$ Differential $\alpha 4(+) /(-) \beta 2$ agonist-binding site contributions to $\alpha 4 \beta 2$ nicotinic acetylcholine receptor function within and between isoforms. J Biol Chem 291:2444-2459.

Mazurov A, Hauser T, and Miller CH (2006) Selective $\alpha 7$ nicotinic acetylcholine receptor ligands. Curr Med Chem 13:1567-1584.

Meyer EM, Kuryatov A, Gerzanich V, Lindstrom J, and Papke RL (1998) Analysis of 3-(4-hydroxy, 2-Methoxybenzylidene)anabaseine selectivity and activity at human and rat alpha-7 nicotinic receptors. J Pharmacol Exp Ther 287 (3):918-925 9864273.

Miller C (1989) Genetic manipulation of ion channels: a new approach to structure and mechanism. Neuron 2:1195-1205.

Morales-Perez CL, Noviello CM, and Hibbs RE (2016) X-ray structure of the human $\alpha 4 \beta 2$ nicotinic receptor. Nature 538:411-415.

Nelson ME, Kuryatov A, Choi CH, Zhou Y, and Lindstrom J (2003) Alternate stoichiometries of $\alpha 4 \beta 2$ nicotinic acetylcholine receptors. Mol Pharmacol 63:332-341.

Nemecz A and Taylor P (2011) Creating an $\alpha 7$ nicotinic acetylcholine recognition domain from the acetylcholine-binding protein: crystallographic and ligand selectivity analyses. J Biol Chem 286:42555-42565.

Newcombe J, Chatzidaki A, Sheppard TD, Topf M, and Millar NS (2018) Diversity of nicotinic acetylcholine receptor positive allosteric modulators revealed by mutagenesis and a revised structural model. Mol Pharmacol 93:128-140.

Papke RL (2014) Merging old and new perspectives on nicotinic acetylcholine receptors. Biochem Pharmacol 89:1-11.

Papke RL, Bagdas D, Kulkarni AR, Gould T, AlSharari SD, Thakur GA, and Damaj MI (2015) The analgesic-like properties of the alpha7 nAChR silent agonist NS6740 is associated with non-conducting conformations of the receptor. Neuropharmacology 91:34-42.

Papke RL, Boulter J, Patrick J, and Heinemann S (1989) Single-channel currents of rat neuronal nicotinic acetylcholine receptors expressed in Xenopus oocytes. Neuron 3:589-596.

Papke RL, Horenstein NA, Kulkarni AR, Stokes C, Corrie LW, Maeng CY, and Thakur GA (2014) The activity of GAT107, an allosteric activator and positive modulator of $\alpha 7$ nicotinic acetylcholine receptors (nAChR), is regulated by aromatic amino acids that span the subunit interface. J Biol Chem 289:4515-4531.

Papke RL, Kem WR, Soti F, López-Hernández GY, and Horenstein NA (2009) Activation and desensitization of nicotinic $\alpha 7$-type acetylcholine receptors by benzylidene anabaseines and nicotine. J Pharmacol Exp Ther 329:791-807.

Papke RL, Meyer EM, and de Fiebre CM (1996) Differential discrimination between human and rat a7 nAChR by GTS-21 and its primary metabolite, 4-OH,2 Methoxybenzylidene anabaseine., in 26th Annual Meeting of the Society for Neuroscience $\mathrm{p} 602.4$

Papke RL and Porter Papke JK (2002) Comparative pharmacology of rat and human $\alpha 7$ nAChR conducted with net charge analysis. Br J Pharmacol 137:49-61.

Papke RL and Stokes C (2010) Working with OpusXpress: methods for high volume oocyte experiments. Methods 51:121-133.

Papke RL, Stokes C, Muldoon P, and Imad Damaj M (2013) Similar activity of mecamylamine stereoisomers in vitro and in vivo. Eur $J$ Pharmacol 720: 264-275.

Papke RL, Stokes C, Williams DK, Wang J, and Horenstein NA (2011) Cysteine accessibility analysis of the human alpha7 nicotinic acetylcholine receptor ligandbinding domain identifies L119 as a gatekeeper. Neuropharmacology 60:159-171.

Papke RL and Thinschmidt JS (1998) The correction of alpha7 nicotinic acetylcholine receptor concentration-response relationships in Xenopus oocytes. Neurosci Lett 256:163-166.

Pavlov VA, Ochani M, Yang LH, Gallowitsch-Puerta M, Ochani K, Lin X, Levi J, Parrish WR, Rosas-Ballina M, Czura CJ, et al. (2007) Selective $\alpha 7$-nicotinic 
acetylcholine receptor agonist GTS-21 improves survival in murine endotoxemia and severe sepsis. Crit Care Med 35:1139-1144.

Picciotto MR, Addy NA, Mineur YS, and Brunzell DH (2008) It's not "either/or" activation and desensitization of nicotinic acetylcholine receptors both contribute to behaviors related to nicotine addiction and mood. Prog Neurobiol 84 329-342.

Pieschl RL, Miller R, Jones KM, Post-Munson DJ, Chen P, Newberry K, Benitex Y, Molski T, Morgan D, McDonald IM, et al. (2017) Effects of BMS-902483, an $\alpha 7$ nicotinic acetylcholine receptor partial agonist, on cognition and sensory gating in relation to receptor occupancy in rodents. Eur J Pharmacol 807:1-11.

Post-Munson DJ, Pieschl RL, Molski TF, Graef JD, Hendricson AW, Knox RJ, McDonald IM, Olson RE, Macor JE, Weed MR, et al. (2017) B-973, a novel piperazine positive allosteric modulator of the $\alpha 7$ nicotinic acetylcholine receptor. Eur $J$ Pharmacol 799:16-25.

Prickaerts J, van Goethem NP, Chesworth R, Shapiro G, Boess FG, Methfessel C Reneerkens OA, Flood DG, Hilt D, Gawryl M, et al. (2012) EVP-6124, a novel and selective $\alpha 7$ nicotinic acetylcholine receptor partial agonist, improves memory performance by potentiating the acetylcholine response of $\alpha 7$ nicotinic acetylcholine receptors. Neuropharmacology 62:1099-1110.

Quadri M, Garai S, Thakur GA, Stokes C, Gulsevin A, Horenstein NA, and Papke RL (2019) Macroscopic and microscopic activation of $\alpha 7$ nicotinic acetylcholine receptors by the structurally unrelated allosteric agonist-positive allosteric modulators (ago-PAMs) B-973B and GAT107. Mol Pharmacol 95:43-61.

Rosas-Ballina M, Goldstein RS, Gallowitsch-Puerta M, Yang L, Valdés-Ferrer SI, Patel NB, Chavan S, Al-Abed Y, Yang $\mathrm{H}$, and Tracey KJ (2009) The selective $\alpha 7$ agonist GTS-21 attenuates cytokine production in human whole blood and human monocytes activated by ligands for TLR2, TLR3, TLR4, TLR9, and RAGE. Mol Med 15:195-202.

Rosas-Ballina M and Tracey KJ (2009) Cholinergic control of inflammation. J Intern Med 265:663-679.

Thakur GA, Kulkarni AR, Deschamps JR, and Papke RL (2013) Expeditious synthesis, enantiomeric resolution, and enantiomer functional characterization of (4-(4-bromophenyl)-3a, 4,5,9b-tetrahydro-3H-cyclopenta[c]quinoline-8-sulfonamide (4BP-TQS): an allosteric agonist-positive allosteric modulator of $\alpha 7$ nicotinic acetylcholine receptors. J Med Chem 56:8943-8947.

Uteshev VV, Meyer EM, and Papke RL (2002) Activation and inhibition of native neuronal alpha-bungarotoxin-sensitive nicotinic ACh receptors. Brain Res 948: $33-46$.

Verbitsky M, Rothlin CV, Katz E, and Elgoyhen AB (2000) Mixed nicotinicmuscarinic properties of the $\alpha 9$ nicotinic cholinergic receptor. Neuropharmacology 39:2515-2524.

Wada E, Wada K, Boulter J, Deneris E, Heinemann S, Patrick J, and Swanson LW (1989) Distribution of alpha2, alpha3, alpha4, and beta2 neuronal nicotinic receptor subunit mRNAs in the central nervous system: a hybridization histochemical study in the rat. J Comp Neurol 284:314-335.

Wada K, Ballivet M, Boulter J, Connolly J, Wada E, Deneris ES, Swanson LW, Heinemann S, and Patrick J (1988) Functional expression of a new pharmacological subtype of brain nicotinic acetylcholine receptor. Science 240:330-334

Wallace TL, Callahan PM, Tehim A, Bertrand D, Tombaugh G, Wang S, Xie W, Rowe WB, Ong V, Graham E, et al. (2011) RG3487, a novel nicotinic $\alpha 7$ receptor partial agonist, improves cognition and sensorimotor gating in rodents. J Pharmacol Exp Ther 336:242-253.

Walsh RM Jr, Roh SH, Gharpure A, Morales-Perez CL, Teng J, and Hibbs RE (2018) Structural principles of distinct assemblies of the human $\alpha 4 \beta 2$ nicotinic receptor. Nature 557:261-265.

Wang H, Yu M, Ochani M, Amella CA, Tanovic M, Susarla S, Li JH, Wang H, Yang H, Ulloa L, et al. (2003) Nicotinic acetylcholine receptor $\alpha 7$ subunit is an essential regulator of inflammation. Nature 421:384-388.

Williams DK, Peng C, Kimbrell MR, and Papke RL (2012) Intrinsically low open probability of $\alpha 7$ nicotinic acetylcholine receptors can be overcome by positive allosteric modulation and serum factors leading to the generation of excitotoxic currents at physiological temperatures. Mol Pharmacol 82:746-759.

Williams DK, Wang J, and Papke RL (2011a) Investigation of the molecular mechanism of the $\alpha 7$ nicotinic acetylcholine receptor positive allosteric modulator PNU120596 provides evidence for two distinct desensitized states. Mol Pharmacol 80: 1013-1032.

Williams DK, Wang J, and Papke RL (2011b) Positive allosteric modulators as an approach to nicotinic acetylcholine receptor-targeted therapeutics: advantages and limitations. Biochem Pharmacol 82:915-930.

Young GT, Zwart R, Walker AS, Sher E, and Millar NS (2008) Potentiation of $\alpha 7$ nicotinic acetylcholine receptors via an allosteric transmembrane site. Proc Nat Acad Sci USA 105:14686-14691.

Zakrzewicz A, Richter K, Agné A, Wilker S, Siebers K, Fink B, Krasteva-Christ G, Althaus M, Padberg W, Hone AJ, et al. (2017) Canonical and novel non-canonical cholinergic agonists inhibit ATP-induced release of monocytic interleukin- $1 \beta$ via different combinations of nicotinic acetylcholine receptor subunits $\alpha 7, \alpha 9$ and $\alpha 10$. Front Cell Neurosci 11:189.

Zhou Y, Nelson ME, Kuryatov A, Choi C, Cooper J, and Lindstrom J (2003) Human $\alpha 4 \beta 2$ acetylcholine receptors formed from linked subunits. J Neurosci 23: 9004-9015.

Address correspondence to: Roger L. Papke, Department of Pharmacology and Therapeutics, University of Florida, P.O. Box 100267, Gainesville, FL 32610-0267. E-mail: rlpapke@ufl.edu 